\title{
Individual study in problem-based learning : studies on the relation between individual study and curriculum characteristics
}

Citation for published version (APA):

van den Hurk, M. (1999). Individual study in problem-based learning : studies on the relation between individual study and curriculum characteristics. [Doctoral Thesis, Maastricht University]. Universiteit Maastricht. https://doi.org/10.26481/dis.19991029mh

Document status and date:

Published: 01/01/1999

DOI:

10.26481/dis.19991029mh

Document Version:

Publisher's PDF, also known as Version of record

Please check the document version of this publication:

- A submitted manuscript is the version of the article upon submission and before peer-review. There can be important differences between the submitted version and the official published version of record.

People interested in the research are advised to contact the author for the final version of the publication, or visit the DOI to the publisher's website.

- The final author version and the galley proof are versions of the publication after peer review.

- The final published version features the final layout of the paper including the volume, issue and page numbers.

Link to publication

\footnotetext{
General rights rights.

- You may freely distribute the URL identifying the publication in the public portal. please follow below link for the End User Agreement:

www.umlib.nl/taverne-license

Take down policy

If you believe that this document breaches copyright please contact us at:

repository@maastrichtuniversity.nl

providing details and we will investigate your claim.
}

Copyright and moral rights for the publications made accessible in the public portal are retained by the authors and/or other copyright owners and it is a condition of accessing publications that users recognise and abide by the legal requirements associated with these

- Users may download and print one copy of any publication from the public portal for the purpose of private study or research.

- You may not further distribute the material or use it for any profit-making activity or commercial gain

If the publication is distributed under the terms of Article 25fa of the Dutch Copyright Act, indicated by the "Taverne" license above, 


\section{Individual Study in Problem-Based Learning}

Studies on the relation between

individual study and

curriculum characteristics 


\section{ni ybute Iswbivibnt

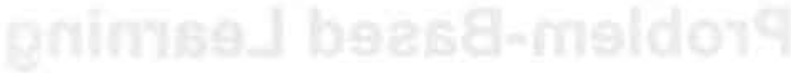




\title{
Individual Study in Problem-Based Learning
}

\author{
Studies on the relation between \\ individual study and \\ curriculum characteristics
}

\section{PROEFSCHRIFT}

Ter verkrijging van de graad van doctor aan

de Universiteit Maastricht,

op gezag van de Rector Magnificus,

Prof. dr. A.C. Nieuwenhuijzen Kruseman,

volgens het besluit van het College van Decanen,

in het openbaar te verdedigen

op vrijdag 29 oktober 1999 om 14.00 uur

door

Maria Mathea van den Hurk

geboren te Veghel in 1966 
Promotor:

Prof.dr. C.P.M. van der Vleuten

Co-promotoren:

Dr. H.A.P. Wolfhagen

Dr. D.H.J.M. Dolmans

Beoordelingscommissie:

Prof. dr. H.G. Schmidt (voorzitter)

Prof. dr. C.A. Bruggeman

Dr. A.J.J.A. Scherpbier

Prof. dr. P.R.J. Simons (Katholieke Universiteit Nijmegen)

Prof. dr. J.D.H.M. Vermunt

Illustratie kaft: P.C.M. Langenhuizen

(C) Marianne van den Hurk, Maastricht, 1999

ISBN 90-9013156-6

Druk: Datawyse Universitaire Pers Maastricht 
loor mijn moeder 



\section{Contents}

2 The relation between time spent on individual study and academic achievement in a problem-based curriculum

Published in Advances in Health Sciences Education, 3, 1, 43-49, 1998

M.M. van den Hurk, H.A.P. Wolfhagen, D.H.J.M. Dolmans and C.P.M. van der Vleuten

3 Student-generated learning issues: A guide for individual study?

33

Published in Education for Health, 12, 2, 213-221, 1999

M.M. van den Hurk, H.A.P. Wolfhagen, D.H.J.M. Dolmans and C.P.M. van der Vleuten

4 Essential characteristics of student-generated learning issues in a problem-based curriculum

Published in Medical Teacher, 20, 4, 307-309, 1998

M.M. van den Hurk, D.H.J.M. Dolmans, H.A.P. Wolfhagen and C.P.M. van der Vleuten

5 The impact of student-generated learning issues on individual study time and academic achievement

Accepted for publication in Medical Education

M.M. van den Hurk, H.A.P. Wolfhagen, D.H.J.M. Dolmans and C.P.M. van der Vleuten

6 Impact of individual study on tutorial group discussion

Published in Teaching and Learning in Medicine, 11, 4, 196-201, 1999

M.M.van den Hurk, D.H.J.M. Dolmans, H.A.P. Wolfhagen, A.M.M. Muijtjens and

C.P.M. van der Vleuten 
7 Testing a causal model for learning in a problem-based curriculum

Submitted to British Journal of Educational Psychology

M.M. van den Hurk, D.H.J.M. Dolmans, H.A.P. Wolfhagen and C.P.M. van der Vleuten

8 Conclusions and Implications

Summary

Samenvatting

Dankwoord

Curriculum Vitae 


\section{Introduction}

Current theories in the science of learning emphasize the importance of active learning. Substantial evidence suggests that competence is fostered not primarily by teaching to deliver knowledge, but through teaching to engender specific kinds of cognitive activity (Glaser, 1991). These ideas and findings have led to the development of curricula that aim to foster students' ability to become architects of their own knowledge. Problem-based leaming (PBL) is assumed to be an instructional approach complying with these current theories in research on the science of learning. In this introduction, some of the current theoretical ideas and findings on learning are described. In addition. two ideas and findings on instruction are described and an outline is given of how in PBL ideas of learning and instruction are applied to educational practice. This introduction ends with a description of the research questions of this thesis and an overview of the contents of chapters is included.

\section{Evidence on learning}

PBL is an approach, as argued above, that can be considered as a systematic attempt to apply findings of cognitive psychology to educational practice. In this section a number of studies are described that provide empirical evidence for those cognitive processes that are reflected in PBL: prior knowledge, elaboration, context of learning, metacognition, intrinsic motivation and active learning. 


\section{Chapter I}

\section{Prior knowledge}

A central and consistent finding from research is that what students already know about a subject is the most important determinant of the nature and amount of new information that can be processed (Anderson, 1977; Schmidt, 1984). Thus, what students learn is to a large extent a function of their prior knowledge about a subject. However, the presence of relevant prior knowledge is not a sufficient condition for understunding and remembering new information. Students generally have substantial knowledge about different topics but they are not always aware of that knowledge. To establish relationships between the existing knowledge and the new information, relevant knowledge should be activated by cues in the context in which the new information is processed (Bransford \& Johnson, 1972; Spires \& Donley, 1998). Thus, stimulating students to state explicitly what they already know about an issue allows them to become aware of their relevant knowledge base and therefore will facilitate the acquisition of new information.

\section{Elaboration}

Knowledge is structured in networks of related concepts, and as learning occurs, new information is integrated into these existing networks (Bruning, Schraw, \& Ronning, 1995). Strengthening these networks and retrieving the information will be improved when, during learning, elaboration on the material takes place. Elaboration can take several forms, such as discussion, note taking or answering questions. When students elaborate, they will actively relate concepts with each other and they will construct more elaborate conceptualisations (Bargh \& Schul, 1980; Kintsch \& Kintsch, 1995; Levin, 1988; Mayer, 1980). Elaboration is the process of considering a piece of knowledge in a richer, wider context (Regehr \& Norman, 1996). This will facilitate the remembering and the retrieval of the learned information. For example, in a study investigating the influence of elaborating on text learning, Mayer (1980) found that groups who elaborated on a text were able to better aggregate information in a novel way and produced more conceptual information than did groups who didn't elaborate on the text. Thus, elaboration will help students construct rich cognitive models of the problems presented to them, due to which student learning is facilitated.

\section{Context of learning}

Learning in context is considered to make information more accessible for later use. If new knowledge is acquired in the context of some professionally meaningful pro- 
blem or situation, this knowledge is assumed to be more accessible. Accessibility is facilitated because the situational cues that activate the knowledge are stored within the same cognitive structures. Therefore it is important that the context of learning closely matches the context in which the information should be applied in the later profession. For example, Smith, Glenberg and Bjork (1978) have shown in several experiments that students showed improvements in cued recall when the learning context and test context matched. Recall was better for same-context than different-context recall. Thus, new knowledge should be acquired in the context of some professionally meaningful problem or situation because matching context facilitates transfer of knowledge.

\section{Metacognition}

Simons and Kluvers (1994) argue that students should acquire learning skills to prepare, plan, and monitor their own learning process and to reflect on this learning process and on its outcomes. These learning skills refer to metacognition (Bruer, 1993). Metacognition is the awareness of how to control the personal mental processes and the self-regulatory behaviour that accompanies this awareness (Driscoll, 1994). It is a process of self-assessment about knowledge levels and abilities while planning. changing strategies. and evaluating throughout learning. Metacognition is of crucial importance for the development of self-regulated learning strategies. Research has shown that the extent to which students monitor their self-testing in respect to their learning goals is predictive for their performance (de Jong, 1992). Also Glaser (1991) argues that several studies have shown that good students know when and how to use different strategies to understand learning materials. Thus, strategies like active monitoring, conscious control, or executive regulation of mental processes, stimulate students' understanding.

\section{Intrinsic motivation and active learning}

Intrinsic motivation is generally considered a kind of curiosity that drives the student to learn more about a topic (Schmidt, 1993). It is assumed that this drive is entirely internally steered without external reward. Someone who feels the urge to learn will be prepared to spend more time on learning than someone who feels less motivated. According to Hidi (1990), this interest has a positive effect on the cognitive performance of students. Furthermore, if students are motivated they will spent more time on learning, which is subsequently expected to influence achievement (Schmidt, 1993). Discussion will enhance intrinsic interest in subject matter becausc 


\section{Chapter 1}

it involves the learners more actively in the issues at hand (Brown, Collins, \& Duguid, 1989). This activity is important while the quality of learning performance mainly depends on the quality of the student's own learning activities.

In summary, research on learning revealed that activation of prior knowledge and elaboration facilitates student learning. In addition, providing a meaningful context facilitates recall, whereas metacognition is of crucial importance for the development of self-regulated learning strategies and stimulates students' understanding. Furthermore, discussion enhances students' intrinsic interest and motivation in the issues at hand, which will positively influence time spent on learning.

\section{Evidence on instruction}

PBL, is not only an approach that can be considered as a systematic attempt to apply findings of cognitive psychology to educational practice. PBL is also an approach in which findings of research on instruction are applied to educational practice. In this section studies are described that provide empirical evidence for two instructional principles reflected in PBL: instructional time in relation to time for individual learning, and self-directed learning.

\section{Instructional time in relation to time for individual learning}

Research on studying time spent on learning has shown that there is a complex, dynamic interaction among learner characteristics, time factors and instructional variables. Three time variables have been identified that may contribute significantly to variability in achievement across individual students: time allowed or allocated for learning. time spent or engaged in learning. and time actually needed for learning. Achievement is then maximised if time spent increases to the point where it equals the amount of time actually needed to learn (Caroll, 1963; Gettinger, 1985). Research concerning the effects of allocated instruction time on time spent on individual learning, shows that allocated instruction time is a critical factor in instructional design to enhance learning (Van der Drift \& Vos. 1987; Gijselaers \& Schmidt, 1995; Vos, 1985). Vos (1985) for instance, conducted a number of studies about time spent on individual study and time allocated to instruction in various curricula for higher education in the Netherlands. He found that more than 20 
instructional hours per week reduces the time that would otherwise be spent on individual study. When the instructional hours are less than 10 hours per week, the amount of individual study in relation to the instructional time will also be lower. The optimum lies between 10 and 20 instructional hours per week. In this situation, approximately $40 \%$ of instructional time will result in approximately $60 \%$ of time spent on individual study.

\section{Self-directed learning}

Research on learning has revealed that many students are not immediately able to learn independently or to regulate their own learning (Garner, 1988; Zimmerman \& Pons, 1986). This implies that instruction must reduce students' dependence on external regulation by shifting from strongly regulated curricula at the beginning to loosely regulated ones at the end. This shift from strong to loose regulation refers to a scaffolding process. In the process of scaffolding, students are supported via modelling of learning strategies in which guidance will be reduced as students become more skilled in their self-regulation process (Reeve, Palincsar, \& Brown, 1987). In other words, external regulation should be diminished when students know how to regulate their own learning process (Simons, 1993; Simons \& Kluvers, 1994). Vermunt (1992) states that if the external guidance is tuned to students' actual level of self-regulated learning, the self-regulated skills will be improved. However, if the external guidance is diminished without the student being able to perform self-regulated learning activities, "destructive frictions" and poorer learning performance are likely to be the result. Thus, curricula should be characterized by a decrease of external regulation over the years should be tuned to students' level of self-regulated learning and emphasize the development of self-directed learning skills in order to promote a learning style conducive to lifelong learning.

In summary, the educational environment should provide an optimal balance between instructional time and time for individual learning. In addition, curricula should be characterized by a decrease of extemal regulation over the ycars and should emphasize the development of self-directed learning skills. 


\section{Chapter I}

\section{Description of problem-based learning}

Since this thesis deals with PBL. especially how the ideas and theories as described above actually play a role in the way students study in PBL, this section describes how PBI. works in everyday practice. In the problem-based curriculum of the Maastricht medical school students are confronted with problems. A problem consists of a description of a set of phenomena that need some kind of explanation.

For example:

A plumber is visiting the doctor and explains "I woke up this morning and when I was coughing. I had blood in my mouth. I am really concerned because in the last two wceks this happened more than once."

A group of 8 to 10 students, the so-called tutorial group, discusses problems of this kind and tries to explain the phenomena in terms of underlying processes, principles or mechanisms (Schmidt, 1983). The tutorial group meets twice a week during twohour sessions and is guided by a tutor. While analyzing the problem, the tutorial group uses a systematic procedure which consists of seven steps. In the first step, students clarify terms and concepts not readily understood. In the second step the group defines the problem, which means that they describe exactly which phenomena have to be explained. In the example given above, medical students may decide that the problem deals with lung diseases (for example, lung cancer) and with a coughing reflex. The third step is to analyze the problem. Students make use of their prior knowledge about the phenomena described and try to generate explanations for the phenomena. For example, they might argue that cough may be caused by something that is irritating in the bronchial tube or by an inflammation. The coughing might suddenly move a lot of air in the lungs and this may cause a leak in vessels in parts of the pulmonary alveolus and so forth. In the fourth step the various explanations of the problem are summarized into a coherent model of the problem. This step will reveal issues that need further study. The fifth step consists of formulating questions about these unanswered issues. These questions are called student-generated learning issues and are factual or conceptual topics that each group decides must be better understood in order to understand the problem under discussion. Learning issues generated for the problem in this example could be: 
How does a cough reflex work physiologically? How can blood be caused in coughing? The sixth step consists of individual study. During this step, the group members individually collect information with respect to the learning issues. In their search for answers, students use text-books, journals, the Internet, discussions, etcetera. Finally, students inform each other about their individual findings and explain the mechanisms underlying the problem to each other in the next tutorial group session. the seventh step (see for a more detailed description of PBL: Barrows, 1988; Schmidt, 1983, 1993).

\section{Principles of learning and instruction as applied to problem-based learning}

Problem-based learning is assumed to be an instructional approach reflecting scientific principles of the conditions of learning and instruction as described at the beginning of this chapter. The seven steps in PBL reflect these principles. In steps 1 to 3 students clarify, define and analyse the problem by activating everything they already know about the problem. In these steps, students activate their prior knowledge about the subject under discussion and actively elaborate on their knowledge. While discussing and analyzing the problem, students are confronted with gaps in their knowledge or conflicting information. This makes them curious and stimulates them to search for information which will lead to a better understanding of the problem at hand (Barrows \& Tamblyn, 1980). In other words, students become intrinsically motivated. Since problems are presented mostly in the context of some professionally meaningful problem or situation, learning in PBL takes also place within a meaningful context. In the fifth step, students generate learning issues. By means of generating learning issues, students leam to reflect upon and control their own learning and develop self-directed learning skills (Barrows, 1988). During individual study, the sixth step, students leam how to conduct literature searches themselves and learn to find the necessary materials independently. These activities are also supposed to stimulate the development of students' self-directed learning skills (Blumberg \& Michael, 1992; Dolmans. 1994; Walton \& Matthews, 1989). When students inform each other about their individual findings and explain the mechanisms underlying the problem to each other, the seventh step, they evaluate what they have learned during individual study. In other 
words, during step seven students learn to reflect upon and control their own learning activities and develop metacognitive skills.

Finally, in PBL students meet twice a week during two-hour tutorial group session. which serve as an organiser for their learning. In addition to these tutorial groups, students in the Maastricht medical school are confronted with lectures, practicals and skills training sessions. However, scheduled activities are kept at a minimum in order to ensure that there will be enough time left for individual study. Of the total amount for learning in PBL in the Mastricht medical school about $40 \%$ is scheduled for instruction which leaves $60 \%$ for individual study. Thus, there is an optimal halance between instructional time versus time for individual learning.

\section{Research questions}

The previous section described why a problem-based curriculum is assumed to be an instructional approach reflecting the principles of learning and instruction as described at the start of this chapter. However, so far little is known about how the various notions about learning and theories as described above actually play a role in the way students learn in PBL, especially how during individual study some of the ideas mentioned influence student learning. For example, there is some evidence that students in a problem-based curriculum develop themselves as self-directed learners (Ryan, 1993; Saunders, Northup, \& Mennin, 1985; Vernon \& Blake, 1993) and that student-generated learning issues play a role in that process (Blumberg, Michael, \& Zeitz, 1990; Hmelo, Gotterer, \& Bransford, 1997). However, it is not yet clear to what extent leaming issues direct students' individual study and how the discussion in the tutorial group influences the generation of learning issues. In addition, the relation between students' individual study and the reporting in the tutorial group is still a black box that needs further investigation. Furthermore, little is known about how these activities in the tutorial group influence what students actually learn and how these activities are related to student achievement. How ideas and findings on learning and instruction play a role in student learning in PBL, and especially how the steps preceding and following individual study in PBL influence individual study and student learning, is subject of this thesis. Three main research topics are addressed. First, what is the impact of time spent during individual study on achievement (chapter 2)? Second, what is the influence of student-generated learning issues on individual study (chapters 3 to 5)? Finally, what is the relation 
between individual study and the reporting in the tutorial group (chapters 6 to 7)? How these questions are related to each other and the chapters included in this thesis, is outlined in Figure 1.1.

Figure 1.1. Model of research questions addressed in this thesis and chapter overview.

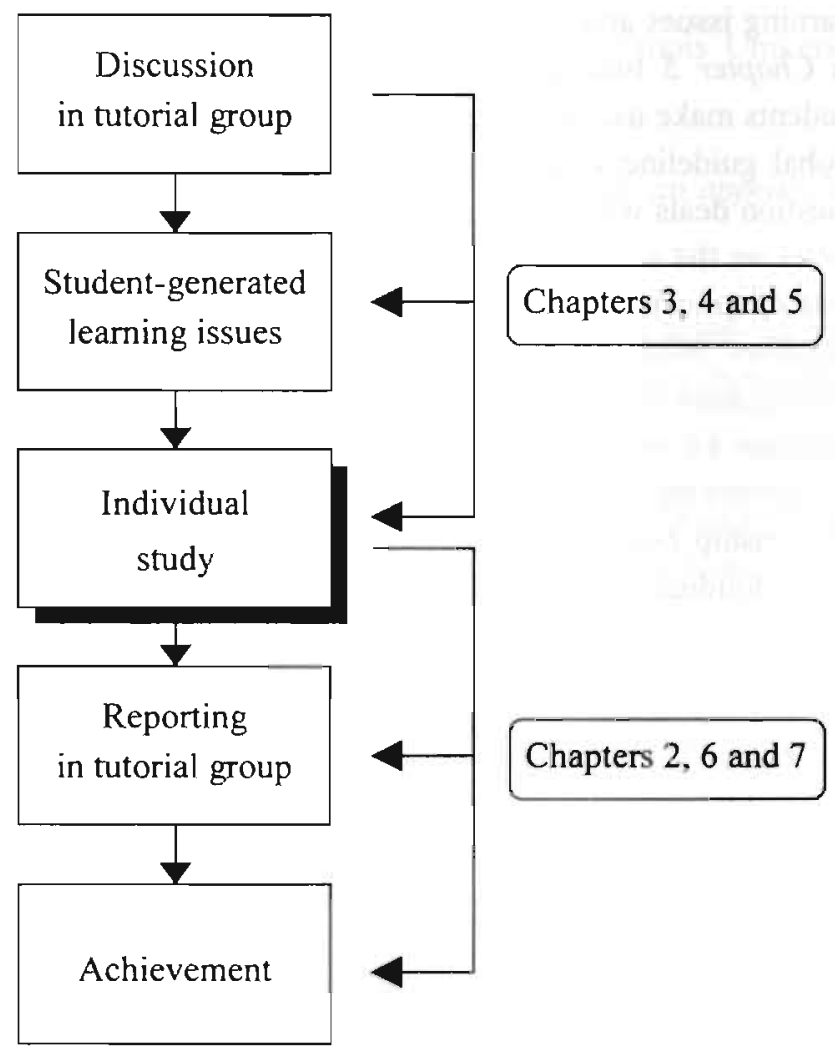




\section{Research questions}

Chapter 2 deals with the question whether a relation exists between the amount of time spent on individual study and academic achievement and whether this differs when using a test measuring short-term knowledge or a test measuring long-term knowledge. The focus of Chapter 3 is on determinants which influence the generation of useful learning issues. Furthermore, in this chapter the use of learning issues during individual study and factors influencing selection of learning resources are examined. Chapter 4 focuses on essential characteristics of student-generated learning issues and how important these characteristics are in each year of training. In Chapter 5 two questions are addressed. The first question concerns the way students make use of the learning issues they generate (i.e., as strict guidelines or as global guidelines) and whether this changes across years of training. The second question deals with the relation between the way students make use of the learning issues on the one hand and time spent on individual study and achievement on two tests of knowledge on the other hand. Chapter 6 deals with how individual study activities influence the discussion in the tutorial group. The question under investigation is whether searching for different literature resources and preparing the literature by making summaries in order to explain the subject matter to someone else affects the quality of the reporting phase. The aim of Chapter 7 is to identify the relationship between variables which are important for the tutorial group process and individual study. Finally, this thesis is based on six articles of which five have been published and one has been submitted. Therefore, every chapter has been written to be read independently which inevitably leads to overlap across chapters. 


\section{References}

Anderson, R.C. (1977). The notion of schemata and the educational enterprise: General discussion of the conference. In R.C. Anderson, R.J. Spiro. \& W.E. Montague, (Eds.), Schooling and the acquisition of knowledge. Hillsdale. Erlba.

Bargh, J.A., \& Schul, Y. (1980). On the cognitive benefits of teaching. Journul of Educational Psychology, 72, 593-604.

Barrows, H.S. (1988). The tutorial process. Illinois: Southern Illinois University School of Medicine.

Barrows, H.S., \& Tamblyn, R.M. (1980). Problem-based learning: an approach to medical education. New York: Springer Publising Company.

Blumberg, P., \& Michael, J.A. (1992). Development of self-directed learning behaviours in a partially teacher-directed problem-based learning curriculum. Teaching and Learning in Medicine, 4(1), 3-8.

Blumberg, P., Michael, J.A. \& Zeitz, H. (1990). Roles of student-generated learning issues in problem-based learning. Teaching and Learning in Medicine, 2, 149154.

Bransford, J.D., \& Johnson, M.K. (1972). Contextual prerequisites for understanding: Some investigations of comprehension and recall. Journal of Verbal Learning and Verbal Behaviour, 11, 717-726.

Brown, J.D., Collins, A., \& Duguid, P. (1989). Situated cognition and the culture of learning. Educational Researcher, 18(1), 32-42.

Bruer, J. (1993). Schools for thought: a science of learning in the classroom. Cambridge: MIT Press.

Bruning, R., Schraw, G., \& Ronning, R. (1995). Cognitive Psychology and Instruction. New Jersey: Merrill. 


\section{Chapter 1}

Caroll, J.B. (1963). A model of school learning. Teachers College Record, 64, 723733.

De Jong, F.P.C.M. (1992). Zelfstandig leren. Regulatie van het leerproces en leren reguleren: een procesbenadering. [Autonomous learning. Regulation of the learning process and learning to regulate: a process approach]. Tilburg: University of Tilburg.

Dolmans, D.H.J.M. (1994). How students learn in a problem-based curriculum. Maastricht: University of Maastricht.

Driscoll, M. (1994). Psychology of learning for instruction. Toronto: Allyn and Bacon.

Garner, R. (1988). Metacognition and reading comprehension. Norwood: Ablex Publishing Corporation.

Gettinger, M. (1985). Time allocated and time spent relative to time needed for learning as determinants of achievement. Journal of Educational Psychology, 77, 3-11.

Gijselaers, W.H., \& Schmidt, H.G. (1995). Effects of quantity of instruction on time spent on learning and achievement. Educational Research and Evaluation, $J(2), 183-201$.

Glaser, R. (1991). The maturing of the relationship between the science of learning and cognition and educational practice. Learning and Instruction, 1, 129-144.

Hidi, S. (1990). Interest and its contribution as a mental resource for learning. Review of Educational Research, 60(4), 549-571.

Hmelo, C.E., Gotterer, G.S., \& Bransford J.D. (1997). A theory-driven approach to assessing the cognitive effects of PBL. Instructional Science, 25, 287-408. 
Kintsch, E., \& Kintsch, W. (1995). Strategies to promote active learning from text: Individual differences in background. Swiss Journal of Psychology, 54(2), 141-151.

Levin, J.R. (1988). Elaboration-based learning strategies: Powerful theory = powerful application. Contemporary Educational Psychology, 13, 191-205.

Mayer, R.E. (1980). Elaboration techniques that increase the meaningfulness of technical text: An experimental test of the learning strategy hypotheses. Journal of Educational Psychology, 72(6), 770-784.

Reeve, R.A., Palincsar, A.S., \& Brown, A.L. (1987). Everyday and academic thinking: implications for learning and problem solving. Journal of Curriculum Studies, $19(2), 123-133$.

Regehr, G., \& Norman, G.R. (1996). Issues in cognitive psychology: implications for professional education. Academic Medicine, 71, 988-1001.

Ryan, G. (1993). Student perceptions about self-directed learning in a professional course implementing problem-based learning. Studies in Higher Education, 18, 53-63.

Saunders, K., Northup, D.E., \& Mennin, S.P. (1985). The library in a problem-based curriculum. In A. Kaufman (Ed.), Implementing problem-based medical education (pp. 291-314). New York: Springer Publishing Company.

Schmidt, H.G. (1983). Problem-based learning: Rationale and description. Medical Education, 17, 11-16.

Schmidt, H.G. (1984). Activatie van voorkennis en tekstverwerking. [Activation of prior knowledge and text processing]. Nederlands Tijdschrift voor de Psychologie, 39, 335-347.

Schmidt, H.G. (1993). Foundations of problem-based learning: some explanatory notes. Medical Education, 27, 422-432. 
Simons, P.R.J. (1993). Constructive learning: the role of the learner. In T.M. Duffy, J. Lowyck \& D.H. Jonassen (Eds.), Designing Environments for constructive learning (pp. 291-314). New York: Springer Verlag.

Simons, P.R.J., \& Kluvers, C. (1994). Tussen verantwoordelijkheid in geven en nemen (Between giving and taking responsibility). MESO-Magazine, 14, 7479.

Smith, S.M., Glenberg, A., \& Bjork, R.A. (1978). Environmental context and human memory. Memory and Cognition, 6(4), 342-353.

Spires, H.A., \& Donley, J. (1998). Prior knowledge activation: Inducing engagement with informational texts. Journal of Educational Psychology, 90(2), 249-260.

Van der Drift, K.D.J.M., \& Vos, P. (1987). Anatomie van een leeromgeving: een onderwijseconomische analyse van universitair onderwijs. [Anatomy of a learning environment: An education-economic analysis of higher education]. Lisse: Swets \& Zeitlinger.

Vermunt, J.D.H.M. (1992). Leerstijlen en sturen van leerprocessen in het hoger onderwijs: naar procesgerichte instructie in zelfstandig denken (Learning styles and regulation of learning in higher education: towards process-oriented instruction in autonomous thinking). Lisse: Swets \& Zeitlinger.

Vernon, D.T., \& Blake, R.L. (1993). Does problem-based learning work? A meta-analysis of evaluative research. Academic Medicine, 68, 550-563.

Vos, P. (1985). Zelfstudie als functie van onderwijsdeelname: hypothesetoetsing. Tijdschrift voor Onderwijsresearch, 10(5), 228-238.

Walton, H.J., \& Matthews, M.B. (1989). Essentials of problem-based learning. Medical Education, 23, 542-58.

Zimmerman, B.J., \& Pons, M.M. (1986). Development of a structured interview for assessing student use of self-regulated learning strategies. American Educational Research Journal, 23(4) 614-628. 


\title{
The relation between time spent on individual
} study and academic achievement in a problem-based curriculum ${ }^{1}$

\begin{abstract}
Logically a relation is expected between time spent on individual study and achievement. The purpose of this study is to examine whether a positive relation exists between the amount of time spent on individual study and academic achievement and whether this differs when using a test measuring short-term knowledge or one measuring long-term knowledge. Data were collected in a problem-based medical curriculum. The results suggest that time spent on individual study correlates poorly with scores on the test measuring short-term knowledge but also with those on a test measuring long-term knowledge. This study reaffirms the complexity of this relationship and it demonstrates the importance to search for qualitative factors about the way students learn.
\end{abstract}

Published in Advances in Health Sciences Education, 3, 1, 43-49, 1998

M.M. van den Hurk, H.A.P. Wolfhagen, D.H.J.M. Dolmans and C.P.M. van der Vleuten 


\section{Introduction}

The majority of studies investigating the relation between time spent on study and academic achievement report a positive relation between these two variables. liredrick and Walberg (1980) reviewed twenty-five studies in this area. Thirteen studies investigated the relation of hours of classes or minutes of study and achievement. These studies all showed positive correlations varying from 0.13 to 0.59 , depending on how time was operationalized. Only two studies found a very poor relationship. For instance, Schuman, Walsh, Olson, and Etheridge (1985) investigated the relation between time spent on individual study and the level of achievement. Correlations varied from a non-significant -0.02 to a significant but low value of 0.11. Van Deynse, Smet, Henderikx and de Neve (1984) found a somewhat higher correlation $(\mathrm{r}=0.24)$ in his study between time spent on individual study and level of achievement. Although the measurement was not always defined equally in these studies, most research on the influence of time-related variables on achievement has shown that time spent on study does play a role in influencing achievement.

Level of achievement has usually been measured by a test that students complete shortly after a certain study effort or course. It is less clear what the effect of time spent on individual study is over a longer period of time. In an assessment of achievement focussing on long term-knowledge, study strategies like memorizing shortly before the test are expected to be less effective. On the contrary, students who study a large amount of time on a regular basis are expected to have better scores on such an assessment. Therefore, the purpose of this study is to examine whether the relation between time spent on individual study and test scores differs according to whether a test measures short-term or long-term knowledge.

The studies described above have mostly been conducted in traditional educational programmes where time available for individual study is often limited and substantial time is scheduled for classroom instruction. Sufficient time for individual study might be an important factor when studying the relation between individual study time and academic achievement. When more time is available for individual study in an educational program, more variation in time spent on individual study among students can be expected. This study was conducted in a curriculum that is based on the principles of problem-based learning (Schmidt, 1983). In this problembased curriculum $40 \%$ of the total scheduled learning time is allocated for 
instruction and $60 \%$ for individual study (Van der Vleuten, Scherpbier, Wijnen, \& Snellen, 1996). Sufficient time is therefore available to spend on individual study.

\section{Method}

\section{Materials}

Data were collected from the four pre-clinical years of the Medical School of the Maastricht University, in the academic year 1994-1995. In both the first and second pre-clinical year about 200 students participated in the study and in the third and fourth year about 150 students participated. In the first and second year more students are in the program because of changing government policy with regard to the fixed student enrolment. Each year consists of seven courses of six weeks called blocks. Five blocks, spread over the four years, were not included in this study because these are elective periods. Time spent on individual study was measured by a self-report procedure. After each block of six weeks students were asked to estimate the average amount spent on individual study per week during that block. A study of Moust (1993), also described by Gijselaers and Schmidt (1995), showed that this method provides a reliable and reasonable valid indicator of time spent on individual study.

The dependent variable, academic achievement, was measured by using the scores of individual students on two different test-methods.

The first one was the block-test which assesses short-term knowledge. In general the block-test, taken after each block, reflects the content of the foregoing block of six weeks. The major goal of the block-test is to assess students' knowledge about the block contents and to provide students with information about their mastery of the course objectives. It consists of 160 to 190 questions of the true/false format with an 'I don't know' option (the question-mark option). Students are required to complete the block-test immediately after the end of each six-week block. A correct answer is rewarded with one mark while an incorrect answer is given a negative mark. The question mark scored neutral. In this study, for each student the correct minus incorrect score was used for all block-tests.

The other test was the progress-test which assesses long-term knowledge. In general, all students of every level are required periodically to take the progress-test, a large test at graduate level, sampled from the total medical body of knowledge, four times a year (Van der Vleuten, Verwijnen, \& Wijnen, 1996). Students cannot prepare 
themselves for the progress-test. Each test consists of approximately 250 true/false items, with a question mark option. In this study, the score of each student was the number of correct answers minus incorrect answers. The question mark scored neutral.

\section{Procedure}

Correlations with time spent on individual study and block-test scores for each block were calculated. In addition, the scores on three progress-tests were used. These progress-tests were taken in December 1994, March and May 1995. Time spent on individual study was measured after each block of six weeks. Subsequently the mean scores of the time that a student reported in the blocks preceding that particular progress-test were averaged per year. For example, prior to the March progress-test students in year one followed four blocks. The total time spent on individual study for these four blocks was calculated and divided by four. This mean time score was correlated with the progress-test score per student. All correlation coefficients were also transformed into a Fisher- $\mathbf{z}$ coefficient. This $\mathbf{z}$ coefficient has a normal sampling distribution regardless of the size of $\mathrm{N}$ and the size of population $\mathbf{r}$.

\section{Results}

On average $65 \%$ of all students indicated the time they spent on individual study. It is conceivable that students who did not respond on the question about the time spent on individual study had a deviant score on one or more of the tests. A check on the dependent variables used in this study, however, revealed no significant differences between the response and non-response group. Only from a few students were one or more test scores lacking. Table 2.1 indicates the mean time spent in hours on individual study per week in each block. The lowest time spent on individual study is 10 hours per week $(S D=6)$ at the end of the second year. The highest time spent on individual study is 21 hours per week and this was during the second block of the fourth year $(S D=8)$. 
Table 2.1. Mean time spent on individual study in hours per week (M), standard deviation (SD) and number of students per block (N).

Blocks

\begin{tabular}{|c|c|c|c|c|c|c|c|c|c|c|c|c|c|c|c|c|c|c|c|c|c|}
\hline & \multicolumn{3}{|c|}{1} & \multicolumn{3}{|c|}{2} & \multicolumn{3}{|c|}{3} & \multicolumn{3}{|c|}{4} & \multicolumn{3}{|c|}{5} & \multicolumn{3}{|c|}{6} & \multicolumn{3}{|c|}{7} \\
\hline & $\mathrm{M}$ & SD & $N$ & $\mathrm{M}$ & SD & $\mathrm{N}$ & $M$ & $\mathrm{SD}$ & $\mathrm{N}$ & $\mathrm{M}$ & SD & $\mathrm{N}$ & M & $\mathrm{SD}$ & $N$ & M & $\mathrm{SD}$ & $\mathrm{N}$ & $M$ & SD & $\mathrm{N}$ \\
\hline Year 1 & 14 & 7 & 136 & 18 & 8 & 115 & 17 & 9 & 116 & 19 & 8 & 119 & 11 & 8 & 116 & - & - & - - & 11 & 8 & 118 \\
\hline Year 2 & 17 & 8 & 109 & 18 & 8 & 111 & $\cdots$ & $\cdots$ & - & 12 & 8 & 99 & 14 & 9 & 110 & 19 & 9 & 95 & 10 & 6 & 96 \\
\hline Year 3 & 17 & 8 & 100 & 17 & 8 & 101 & 12 & 8 & 90 & - & $\cdots$ & - - & 17 & 7 & 90 & 15 & 7 & 88 & 12 & 7 & 85 \\
\hline Year 4 & 20 & 7 & 107 & 21 & 8 & 98 & 17 & 8 & 97 & 19 & 7 & 93 & 12 & 7 & 90 & - & $\cdots$ & $\cdots$ & - & - & - - \\
\hline
\end{tabular}

- Elective blocks were excluded

The mean scores, expressed in the percentage correct minus incorrect answers, on the block-test in the first year ranged from $38(S D=13)$ to $46(S D=13)$, in the second year the mean score ranged from $38(S D=10)$ to $44(S D=15)$.

Figure 2.1. Mean scores on progress-test per year.

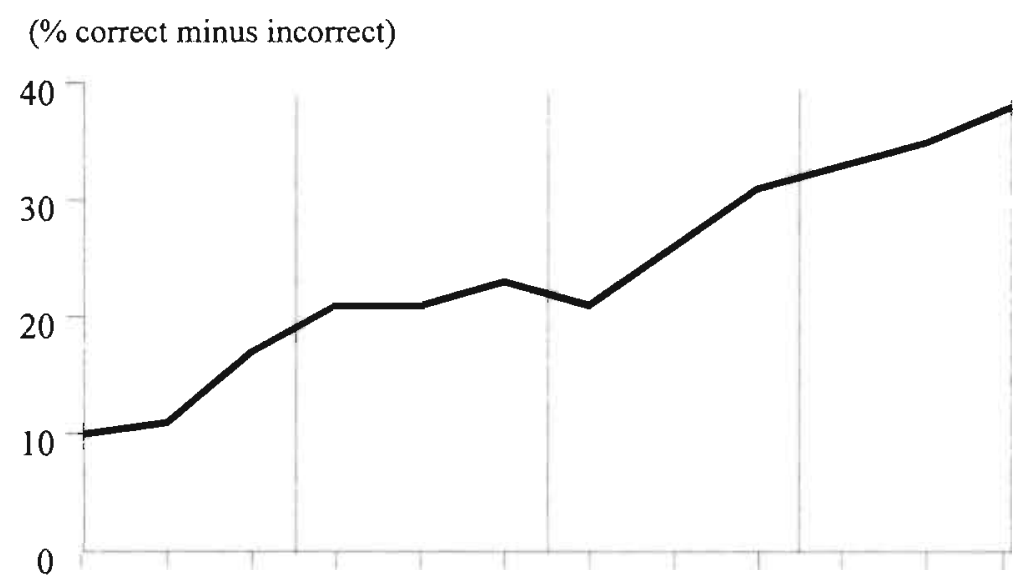

Dec March May Dec March May Dec March May Dec March May $\begin{array}{llll}\text { Year } 1 & \text { Year } 2 & \text { Year } 3 & \text { Year } 4\end{array}$ 
In the third year the lowest mean score on the block-test was $28(S D=10)$ and the highest was $47(S D=10)$. In the fourth year the mean score ranged from $37(S D=$ $10)$ to $48(S D=10)$.

Figure 2.1 shows the progress in time expressed as percentage correct minus incorrect answers on three progress-tests in each year. It shows that the mean scores increase over the four years and within each year.

The Pearson correlation coefficients for time spent on individual study and the scores on the block-test are presented in Table 2.2. Over the four years a variation ranging from a significant negative correlation of -0.29 to a significant positive correlation of 0.32 is found.

In the first block in the first year a significant but negative $(-0.29)$ correlation between time spent on individual study and the score on the block-test is found. In the second year none of the correlations are significant. In the third year, however, in four of the six blocks the time spent correlates significantly with the block-test score. In the fourth year, in two of the five blocks does time spent on individual study correlate significantly with the block-test score.

Table 2.2. Pearson correlation coefficients $(r)$ and Fisher $r\left(Z_{r}\right)$ between time spent on individual study and the scores on the block-test.

Blocks

$\frac{1}{r \quad\left(Z_{r}\right)} \frac{2}{r \quad\left(Z_{r}\right)} \frac{3}{r \quad\left(Z_{r}\right)} \frac{4}{r \quad\left(Z_{r}\right)} \frac{5}{r \quad\left(Z_{r}\right)} \frac{6}{r \quad\left(Z_{r}\right)} \frac{7}{r \quad\left(Z_{r}\right)}$

$\begin{array}{cccccccc}\text { Year 1 } & -.29 *(-.30) & -.05(-.05) & .06(.06) & -.06(-.06) & -.07(-.07) & -- & .08(.08) \\ \text { Year 2 } & -.05(-.05) & .05(.05) & -- & .02(.02) & .06(.06) & .07(.07) & .03(.03) \\ \text { Year 3 } & .31 *(.32) & .21 *(.21) & .07(.07) & -- & -.03(-.03) & .31 *(.32) & .28^{*}(.29) \\ \text { Year 4 } & .10(.10) & .32 *(.33) & .26 *(.27) & .06(.06) & -.03(-.03) & -- & --\end{array}$

- Elective blocks were excluded $\quad{ }^{*} p<.05$ 
Table 2.3 presents Pearson correlation coefficients for time spent on individual study and the scores on the progress-test. This table shows that time spent does not correlate significantly at any of the measurement moments with a progress-test score. measuring long-term knowledge.

Table 2.3. Pearson correlation coefficients $(r)$ and Fisher $r\left(Z_{r}\right)$ between time spent on individual study and the scores on the progress-test.

Moment of measurement

\begin{tabular}{|c|c|c|c|c|}
\hline December & \multicolumn{2}{|c|}{ March } & & \\
\hline$Z_{\mathrm{r}}$ & r & $Z_{r}$ & $r$ & $Z_{r}$ \\
\hline
\end{tabular}

\begin{tabular}{rrrrrrr} 
Year 1 & -0.01 & $(-0.01)$ & -0.03 & $(-0.03)$ & -0.04 & $(-0.04)$ \\
Year 2 & -0.05 & $(-0.05)$ & 0.07 & $(0.07)$ & 0.06 & $(0.06)$ \\
Year 3 & -0.05 & $(-0.05)$ & 0.06 & $(0.06)$ & 0.13 & $(0.13)$ \\
Year 4 & -0.11 & $(-0.11)$ & -0.03 & $(-0.03)$ & 0.07 & $(0.07)$ \\
\hline
\end{tabular}

\section{Discussion}

The results of this study showed that correlations between time spent on individual study and academic achievement are zero for most blocks, moderate negative for one block and moderate positive for seven blocks and correlations with the progresstest are essentially zero. In the third and fourth year the time students spent on their individual study has more influence on their score on the block-test, but not on their score on the progress-test. Caroll (1963) suggests that students will master instructional objectives to the extent that they have the opportunity and are willing to invest the time needed to learn. To be more specific, three time variables may contribute to variability in achievement across individual students. These are (A) time allowed or allocated for learning; (B) time spent or engaged in learning; and 
(C) time actually needed for learning. Achievement is then maximized if time spent increases to the point where it equals the amount of time actually needed to learn.

In the present study only aspect B (time spent or engaged in learning) is explored. In a problem-based curriculum instruction time is limited and much time is scheduled for individual study. The curriculum leaves compared to more traditional curricula a high amount of time available for individual study. Therefore it is less plausible that aspect $\mathrm{A}$ (time allowed or allocated for learning) gives an explanation for the low correlations. The most plausible explanation can be found in aspect $\mathrm{C}$ (time actually needed for learning). Students probably differ in the time they need to learn related to a level of achievement which can be explained by intelligence, learning styles or the influence of the curriculum. As a consequence, the correlations in year 3 and 4 might be explained by the fact that students know better what time they need to study.

The standard deviations corresponding with the time spent on individual study for each block are relatively high, indicating the existence of large individual variation. This could be a reflection of the subjectivity in the self-rating. However, a secondary analysis using group data of categorized (extreme) data (not reported), did not yield different conclusions; the relationship between classes of scores on the self-rating and classes of scores on the achievement test remained weak and unsystematic.

The low correlations that are found in this study do not implicitly mean that there is no relation at all between time spent on individual study and achievement. It is important to search for more qualitative facts about the way students learn and which factors in the curriculum stimulate study behaviour. The study at least reaffirms the complexity of the relationship, casting doubt upon an intuitive and logical positive association. 


\section{References}

Caroll, J.B. (1963). A model of school learning. Teachers College Record, 64, 723733.

Dickinson, D.J., \& O'Connell, L. (1990). Effects of quality and quantity of study on student grades. Journal of Educational Research, 83(4), 227-231.

Fredrick, W.C., \& Walberg, H.J. (1980). Learning as a function of time. Journal of Educational Research, 73, 183-194.

Gettinger, M. (1985). Time allocated and time spent relative to time needed for learning as determinants of achievement. Journal of Educational Psychology, $77,3-11$.

Gijselaers, W.H., \& Schmidt, H.G. (1995). Effects of quantity of instruction on time spent on learning and achievement. Educational Research and Evaluation, I(2), 183-201.

Moust, J. (1993). De rol van tutoren in probeleemgestuurd onderwijs: contrasten tussen student- en docent-tutoren [The role of tutors in problem-based learning: contrasts between undergraduate teaching assistants and faculty]. Maastricht: University of Maastricht.

Schmidt, H.G. (1983). Problem-based learning: Rationale and description. Medical Education, 17, 11-16.

Schuman, H., Walsh, E., Olson, C., \& Etheridge, B. (1985). Effort and reward: The assumption that college grades are affected by quantity of study. Social Forces, 63, 945-966.

Van Deynse, N., Smet, M., Henderikx, P., \& Neve, H. de. (1984). Studietijden en studieresultaten bij eerstejaars burgerlijk ingenieur aan de K.U. Leuven [Study time and study outcome of first year engineering students of the University of Leuven]. Tijdschrift voor Onderwijsresearch, 9(4), 171-179. 
Van der Vleuten, C.P.M., Scherpbier, A.J.J.A., Wijnen, W.H.F.W., \& Snellen. H.A.M. (1996). Flexibility in learning: a case report on problem-based learning. International Higher Education, 2, 17-24.

Van der Vleuten, C.P.M., Verwijnen, G.M., \& Wijnen, W.H.F.W. (1996). Fifteen years of experience with progress-testing in a problem-based curriculum. Medical Teacher, 18(2), 103-109. 


\section{Student-generated learning issues: A guide for individual study ${ }^{1}$}

\section{Abstract}

In a problem-based curriculum students discuss problems in small group tutorials. Subsequently, students generate learning issues that are the main starting points for their individual study. This study examined three questions: (1) What is the impact of the tutorial group process on generating useful learning issues? (2) When and how are learning issues used during individual study? (3) What determines the choice of literature during individual study? First, interviews were done and a questionnaire was developed which was completed by $492(70 \%)$ students in years 1 to 4 of the Maastricht University Medical School, at the end of the academic year 1995-1996. The results showed that discussions in the tutorial groups, the tutors' functioning, and the quality of problems are important elements in the generation of useful learning issues. Learning issues are mainly us'd at the beginning of individual study and are important influences on the selection of literature for further study. Also important in determining the selections of literature are literature references given to the students and the course objectives.

1 Published in Education for Health, 12, 2, 213-221, 1999

M.M. van den Hurk, H.A.P. Wolfhagen, D.H.J.M. Dolmans and C.P.M. van der Vleuten 


\section{Chapter 3}

\section{Introduction}

The curriculum at the medical school of the Maastricht University follows the principles of problem-based leaming (PBL) (Barrows \& Tamblyn. 1980). A group of 8 to 10 students. guided by a tutor. discusses problems and seek to explain the described phenomena in terms of underlying processes, principles or mechanisms. During this group discussion some questions remain unanswered and require further exploration. The tutorial group decides which issues are essential for a better understanding of the problem at hand (Barrows, 1988, Schmidt, 1993). These are the so-called learning issues and are assumed to be the starting point for students' individual study.

Research on learning issues in a problem-based curriculum has examined whether student-generated learning issues are in line with faculty-designed learning objectives (Coulson \& Osborne, 1984; Dolmans, Gijselaers, Schmidt, \& van der Meer, 1993; Shahabudin, 1987). Dolmans and colleagues (1994) for example, collected information on learning issues generated by 12 tutorial groups over 12 problems in a module. In this study students identified $64 \%$ of the faculty's learning objectives, suggesting that that students in a tutorial group, to a lage extent, can determine what topics are important to be studied.

Blumberg, Michael, and Zeitz (1990) investigated the role of student-generated learning issues and the learning initiatives of students in seven different problembased schools. In five of the seven schools students are assumed to play an active role in generating learning issues, and were evaluated on their ability to generate appropriate learning issues. In these schools students appear to take more learning initiatives and use a wider range of leaming resources compared with the schools in which the learning issues were provided. The authors concluded that for the development of self-directed learning skills, the process of defining and using student-generated learning issues is important. However, it is not clear from that study how learning issues are formulated or what aspects of the group's process contributed to the generation of useful learning issues.

Gijjselaers \& Schmidt (1990) have proposed a theoretical model for guiding investigations of the influence of group behaviour and related factors on the learning process in PBL. Their model describes input. process, and outcome variables. Input variables are prior knowledge, quality of problems, and tutor behaviour. Process variables are study time and group functioning. Outcome variables are learner achievement and interest in subject matter. Their findings related to group- 
functioning variables demonstrate that the quality of the problems used is a key to optimal group functioning. Less important, but still of significance to the group's effectiveness, is the tutor's functioning. Since learning issues are a result of the discussion in the tutorial group, it is likely that these factors are also important determinants of the quality of the learning issues generated.

A major assumption of PBL is that learning issues are the dominant force in driving students" learning activities (Walton \& Matthews, 1989). They are assumed to guide students during the selection of literature. It is also assumed that students use their learning issues subsequently, during their studying and to evaluate whether they have studied enough. There has not yet been, however, an investigation of whether these assumptions are reflected in practice. Perhaps, for example, students use learning issues only to decide what they are going to study and not during studying. Although learning issues are considered to be important for individual study, other aspects in the curriculum may also influence the students' decisions of what to study. To shed some light on what factors are important in generating useful learning issues and what factors influence the ways students accomplish their individual studies, we undertook the research reported here, focussing on the following questions:

1. What is the impact of the tutorial group process (discussion in the tutorial group, tutor, and problems) on generating useful learning issues?

2. When and how are learning issues used during individual study?

3. What determines the choice of literature during individual study?

\section{Method}

\section{Material}

Twelve medical students from years 1 to 4 were interviewed. The aim of the interviews was to explore which factors in the tutorial group process students consider important in generating useful learning issues, and how learning issues, and other aspects, play a role during individual study. Based on these interviews, a questionnaire was developed, consisting of 36 statements that were divided into 10 clusters.

Clusters 1 to 3 concerns the first research question (Which aspects in the tutorial group are important for generating useful learning issues?) The clusters are:

1 Quality of discussion in the tutorial group (5 items); 


\section{Chapter 3}

2 Functioning of the tutor ( 2 items): The expertise and influence of the tutor in the tutorial discussion;

3 Quality of the problems (5 items);

Clusters 4 to 6 relate to the second research question (When and how are learning issues used during the individual study?) The clusters are:

4 When learning issues are used (4 items): Before, during or after studying;

5 How learning issues are used ( 7 items): As a guideline to identify the literature or as a starting point to choose the content of literature;

6 The use of learning issues for preparing the examination (2 items);

Clusters 7 to 10 deals with the third research question (What determines the selection of literature during individual study?) The clusters are:

7 Course objectives in the block book (2 items);

8 Assessment (2 items);

9 Lectures and practical work ( 3 items);

10 Literature references (4 items).

Students were asked to indicate on a 5-point Likert scale to what extent they agreed or disagreed with each statement $(1=$ "completely disagree" to $5=$ "completely agree").

\section{Procedure}

At the end of the 1995-1996 academic year the questionnaire was administered to all medical students of the first four years of the 6-year Maastricht programme. Students were asked to base their answers on the past academic year.

Analyses were initially carried out for all four years. Subsequently, analyses were carried out separately for each year. For each cluster, the mean score per item, and the mean score for each student were computed. To calculate the mean score of each cluster, the mean scores of the items in each cluster were counted and divided by the number of items of that cluster. To assess the reliability of the clusters, Cronbach's alphas were computed (Crowl, 1996). Specific differences between the years of training were analysed with post-hoc analyses, using the Schelfé F-test (Gay, 1992). 


\section{Results}

In total, 495 students completed the questionnaire (response rate $=70 \%$ ). In the first year the response rate was $74 \%(n=161)$, in the second year $73 \%(n=153)$, in the third year $74 \%(n=104)$ and in the fourth year $57 \%(n=77)$.

Table 3.1 shows that the alphas of the clusters vary from 0.48 to 0.70 . Internal consistency of the second (functioning of the tutor), third (quality of problems) and the tenth cluster (literature references) is low. This indicates that the items in each of these clusters are independent and do not form one cluster. Furthermore, the pvalues shown in Table 3.1 show that some clusters are significantly different between the years.

\section{Determinants of useful learning issues}

The results in Figure 3.1 show that generating useful learning issues in all ycars depends on the quality of the discussion in the tutorial group (mean scores vary between 3.5 and 4.0). A requirement is that the quality of the discussion is well structured and students must listen to one another. Compared with students in other years, students in the third year suggest that the quality of the discussion in the tutorial group is less important. Their opinion differs significantly of the opinion in the other years. The functioning of the tutor is also important in generating useful learning issues (mean scores vary between 3.6 and 3.8). No significant differences between the years in the opinion about the importance of tutor functioning are found.

Students in all years report that the quality of a problem is less important, but their scores are still relatively high $(M=3.6)$. Problems should provide sufficient cues for starting the discussion. No significant differences between the years were found. 
Table 3.1. Number of items per cluster (Items), mean score on scale from 1 to 5 (Mean), standard deviation (SD), number of students $(\mathrm{N})$, alpha coefficient (Alpha) and significant differences between years of training (p).

\begin{tabular}{lllllll}
\hline Clusters & Items & Mean & SD & $\mathrm{N}$ & Alpha & $\mathrm{p}$ \\
\hline $\begin{array}{l}\text { Determinants of } \\
\text { Useful learning issues }\end{array}$ & & & & & & \\
1. Discussion tutorial group & 5 & 3.80 & 0.63 & 491 & 0.70 & .000 \\
2. Functioning of tutor & 2 & 3.70 & 0.81 & 495 & 0.50 & .080 \\
3. Quality of problems & 5 & 3.60 & 0.56 & 491 & 0.48 & .081 \\
\hline Use of learning issues & & & & & & \\
4. Moment of using & 4 & 3.40 & 0.83 & 495 & 0.62 & .000 \\
5. Way of using & 7 & 3.50 & 0.64 & 492 & 0.70 & .000 \\
6. Assessment preparation & 2 & 2.20 & 0.98 & 495 & 0.66 & .002 \\
\hline $\begin{array}{l}\text { Determinants of } \\
\text { Literature selection }\end{array}$ & & & & & & \\
7. Course objectives & 2 & 3.30 & 1.00 & 495 & 0.62 & .309 \\
8. Assessment & 2 & 2.60 & 0.83 & 495 & 0.66 & .162 \\
9. Lectures, practical work & 3 & 3.00 & 0.65 & 494 & 0.69 & .000 \\
10. Literature references & 4 & 3.70 & 0.98 & 495 & 0.54 & .121 \\
\hline
\end{tabular}

Significance level: $p<.01$

\section{Use of learning issues}

The results in Figure 3.1 show that the moment students use the learning issues during individual study differs between the years (mean scores vary between 3.0 and 3.6). First-year students use leaming issues most extensively before and during individual study $(M=3.4)$. During the next two years this significantly decreases from 3.6 to 3.0 , rising again slightly in the fourth year $(M=3.3)$. Students report at the item level (data not reported) that they use learning issues especially before they start their individual study $(M=4.2)$. This decreases from 4.4 in the first year to 3.9 in the third year and 4.2 in the fourth year. While studying, students use learning issues less extensively compared with when they start their individual study.

The average of the scores for the cluster of items related to the way students use learning issues during individual study varies between 3.3 and 3.6. Important in this 
cluster is that students use learning issues especially as a guide to select the literature they plan to study. For this cluster, significant differences between the years appear. Learning issues are not extensively used as a guide to prepare for the tests $(M=2.2)$. Only first year students score significantly higher on this cluster, compared with students in other years. However, a mean score of 2.4 suggests that learning issues are not particularly important when preparing for tests.

Figure 3.1. The mean score of each cluster per year. The numbers on the X-axis represent the following factors: 1. Discussion in tutorial group: 2 . Functioning of tutor; 3. Quality of problems; 4 . Moment of using; 5. Way of using; 6 . Assessment preparation; 7. Course objeclives; 8 . Assessment; 9. Lectures and practical work; 10. Literature references.

5. (Scale 1-5)

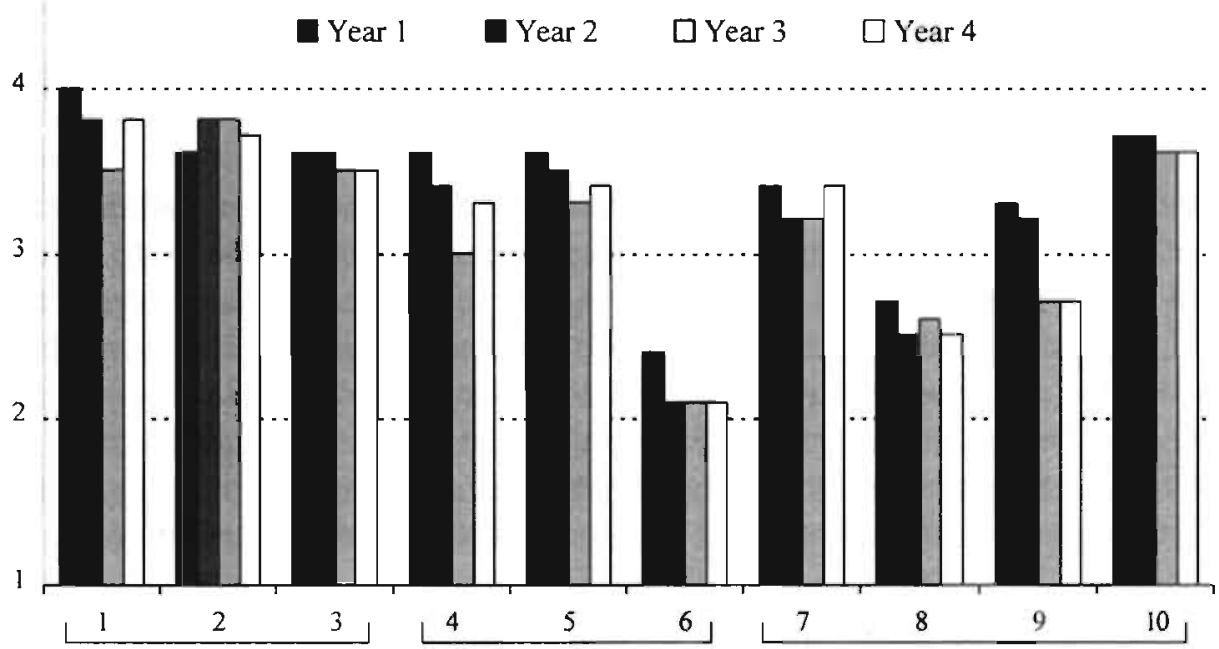

Determinants of useful Use of learning issues learning issues

Determinants of literature selection 
In the third year the lowest mean score on the block-test was $28(S D=10)$ and the highest was $47(S D=10)$. In the fourth year the mean score ranged from $37(S D=$ 10) to $48(S D=10)$.

\section{Determinants of litcrature selection}

The mean scores of the clusters concerning other aspects that influence literature selection show that literature references in the block book or given by the tutor have in all yeirs most impact on the selection of literature (mean scores vary between 3.6 and 3.7). The course objectives also influence the selection of literature (mean scores vary between 3.2 and 3.4). The contents of lectures and practical work have less impact on literature selection $(M=3.0)$. but are significantly different between the years. During the four years the impact of lectures and practical work declines from 3.3 in the first year to 2.7 in the third and fourth year. The influence of assessments on literature selection is low $(M=2.6)$ and not significantly different between the years of training.

\section{Conclusion and discussion}

The first question of this study was concerned with the impact on generating useful learning issues of factors in the tutorial group process (the discussion in the group, the tutor, and the problems). The results suggest that the impact is greater if the discussion in the tutorial group is well structured and students listen to each other. The discussion in the tutorial group is guided by a discussion leader who, in our setting, is always a member of the group. This leader has the important but difficult task of structuring the discussion. Although students are given some training for this role, it can still be difficult being a student-leader of the discussion. It is clearly important that students are trained well for this responsibility.

Whereas the student leader structures the discussion, the content of the discussion is monitored by the tutor. The present study show that students think that for generating useful learning issues, it is important that tutors, when necessary, contribute their content expertise to the discussion. Furthermore, they indicate that problems must lead to sufficient discussion. These findings are consistent with those from the study of Gijselaers \& Schmidt (1990). They also found that tutor behavior and the quality of the problems are important for optimal functioning of the group. 
A limitation of the current study is that it does not make clear what students consider to be useful learning issues. Further research should help clarify the students' perspectives on the essential characteristics of useful learning issues.

The second research question concerned whether learning issues serve as guides during individual study. In the introduction, it was stated that many consider learning issues to be the major force in driving students' learning activities. The results of this study seem to support this view: learning issues are predominantly important for initiating individual study and for determining what topics should be studied. However, during and after studying they appear to be less important. This finding may indicate that students. while pursuing reading, are not strongly focussed on whatever guidance might be provided by their learning issues. However, the results show significant differences between the years. In the first year, students use learning issues more as a guideline (before and during studying) than do students in more senior years. Perhaps first-year students confine themselves more strictly to the content of learning issues while more seasoned students have learned to study also according to their own spontaneous learning needs and interests. This could suggest that, with experience, students in a PBL curriculum become more independent learners. Further research must investigate in more detail how student-generated learning issues play a role in the development of students as independent learners.

The third question was about other factors that play a role in selecting literature for study. Literature references given by the tutor or specified in the blockbook, and the course objectives developed by the faculty all turn out to be important influences on the students' reading decisions. It is not surprising that students focus on these teacher-provided references and objectives when selecting learning resources. The recommended references are related to the content of the problems and provide direction regarding the topics to be studied. They can save students a lot of time. However, those students who undertake their own literature searches can acquire skills that are needed for their future learning. Therefore, detailed or highly targeted reading suggestions and objectives offered by tutors and syllabi may be counterproductive. They may keep the students from learning to make selections themselves. In general it can be concluden that independent study is a core component of effective PBL. The quality and the areas of focus of this independent study help determine the students' learning outcomes. The investigation reported here has reconfirmed earlier findings that learning issues can exert a considerable influence on parts of students' independent study. While this research had limitations, as noted, and it was conducted at only one school, it seems reasonable to 


\section{Chapter 3}

conclude that learning issues are in need of being better understood, and that effective planning for and implementation of PBL requires that close attention be paid to those factors that shape the generation and selection of learning issues. Finally, a limitation of this study is that all the findings derive from student opinions. Although students are in an optimal position to witness and comment upon many of the investigated factors, their primary role is to learn, not to be observers of the processes in which they are engaged. And, they are not necessarily critical observers of these processes at this stage of their development. Therefore, additional studies of the issues investigated here are clearly needed. A desirable strategy in a future study, for example, would involve direct observations, by skilled observers. of the functioning of multiple, different tutorial groups. 


\section{References}

Barrows, H.S., \& Tamblyn, R.M. (1980). Problem-based learning: An approach to medical education. New York: Springer Publishing Company.

Barrows, H.S. (1988). The tutorial process. Springfield, Illinois: Southern Illinois University school of medicine.

Blumberg, P., Michael, J.A., \& Zeitz, H. (1990). Roles of student-generated learning issues in problem-based learning. Teaching and Learning in Medicine, 2, 149 154.

Coulson, R.L., \& Osborne, C.E. (1984). Insuring curricular content in a studentdirected problem-based learning program. In H.G. Schmidt \& M.L. de Volder (Eds.), Tutorials in problem-based learning. A new direction in teaching the health professions (pp. 225-229). Assen: Van Gorcum.

Crowl, T.K. (1996). Fundamentals of educational research. Madison WI: Brown \& Benchmark.

Dolmans, D.H.J.M., Gijselaers, W.H., Schmidt, H.G., \& Van der Meer, S.B.V.D. (1993). Problem effectiveness in a course using problem-based learning. Academic Medicine, 68(3), 207-213.

Gay, L.R. (1992). Educational research: Competencies for analysis and application. New York: Macmillan Publishing Company.

Gijselaers, W.H., \& Schmidt, H.G. (1990). The development and evaluation of a causal model of problem-based learning. In Z. Norman, H.G. Schmidt \& E. Ezzat (Eds.), Innovation in medical education. An evaluation of its present status (pp. 95-113). New York: Springer Publishing Company.

Schmidt, H.G. (1993). Foundations of problem-based learning: Some explanatory notes. Medical Education, 27, 422-432. 


\section{Chapter 3}

Shahabudin. S.H. (1987). Content coverage in problem-based learning. Medical Education, 21,310-313.

Walton. H.J., \& Matthews. M.B. (1989). Essentials of problem-based learning. Medical Education. 3, 542-58. 


\title{
Essential characteristics of student-generated learning issues in a problem-based curriculum ${ }^{1}$
}

\begin{abstract}
In a problem-based curriculum students generate learning issues that are the guidelines for their individual study. This study investigates the essential characteristics of learning issues and the importance are they have in each year of training. Two (free response) questions about characteristics of learning issues were answered by medical students. The response was $69 \%(N=479)$. Students reported three important characteristics which were brought together in one definition: a useful learning issue contains a keyword that demarcates the content of a certain topic to be studied and is formulated concisely and unambiguously for all members of the tutorial group. There were small differences in the importance of the characteristics between years of training.
\end{abstract}

Published in Medical Teacher, 20, 4, 307-309, 1998

M.M. van den Hurk, D.H.J.M. Dolmans, H.A.P. Wolfhagen and C.P.M. van der Vleuten 


\section{Chapter 4}

\section{Introduction}

In a problem-based curriculum students generate learning issues that guide their individual study. These learning issues are generated in small group tutorials. as a result of students discussing problems. A problem consists of a description of a set of phenomena needing some kind of explanation (Barrows, 1980). The discussion provides unanswered questions which serve as a guide for independent and selfdirected learning (Schmidt, 1983). The unanswered questions are called learning issues.

Students take an active role in generating learning issues, deciding how they will study them, and evaluating what they have learned. This process is helpful in the development of students' self-directed, lifelong learning skills (Barrows, 1985, Walton \& Matthews, 1989). Evidence for this assumption is found in a study by Blumberg, Michael and Zeitz (1990) in which they investigated seven different problem-based schools about the role student-generated learning issues play and the learning initiatives of students. In five of the seven schools, students play an active role in generating learning issues, and students are evaluated on their ability to effectively generate appropriate learning issues. In these schools students appear to take more learning initiatives and use a wider array of learning resources. The authors conclude that for the development of self-directed learning skills, the process of defining and using student-generated learning issues is important. Dolmans, Schmidt, and Gijselaers (1995) explored the extent to which studentgenerated learning issues are a major factor influencing students' individual study. They collected the learning issues raised by students, which were then compared with a list of topics faculty expected students to cover during individual study. Students had to indicate how much time they spent on each topic and whether they mastered each topic. Although students generated the learning issues intended by faculty while developing the problems, these issues did not always correlate positively with the topic scores. Thus, what students plan to do, as expressed in the list of learning issues produced after problem discussion, is not always related to what students actually do during individual study. One explanation was that the learning issues generated were perhaps in some cases defined too broadly and as a consequence provide poor guidance for students' individual study. In which cases does a learning issue then provide good guidance for students' individual study? According to Barrows (1985), it is important that learning issues are generated in such a way that they become the tools which provide students with the direction and 
extent of study that must be undertaken to acquire a deeper understanding of the problem. However, little is known about the precise characteristics of learning issues that give students sufficient direction for their individual study. Since learning issues are important guidelines for students 'individual study, it is important to know more about the essential characteristics of learning issues. The goal of this study was to collect more detailed information about the characteristics which make studentgenerated learning issues useful for individual study. Second, the study investigates the importance of characteristics that differentiate between years of training.

\section{Method}

\section{Participants}

The participants were all students of the first four years of training in the academic year 1995-1996 of the Medical School of the University of Maastricht in the Netherlands.

\section{Materials}

Two (free response) questions, as part of a questionnaire about the impact of learning issues on students' individual study, were completed by the students. The first question was "What is the most important characteristic of a useful learning issue?" and the second, "What is the most important characteristic of a learning issue that is not useful?"

\section{Procedure}

All words, sentences and characteristics given by the students on the free response were categorized. For example, a student wrote down the sentence "I think a useful learning issue must always contain a keyword." The word 'keyword' was defined as a characteristic. When words were synonymous with each other, they were classed under the same category. For example, when students reported 'keyword' as an important characteristic, this was classified in the same category as 'headword' or 'catchword'. Three main categories on each question (useful learning issue and not. useful learning issue) were identified. Two educational researchers with expertise in the field of problem-based learning judged all comments. When the judges disagreed on the classification, a discussion was held and consensus was reached. A few words 


\section{Chapter 4}

were classified as 'miscellaneous' when more infrequent characteristics were encountered.

\section{Results}

Students" ideas about what makes a learning issue effective could be classified in three categories: (1) keyword, (2) concise, (3) unambiguous. Each category will be outlined below.

\section{Keyword}

First, students reported that a useful learning issue should contain a keyword or headword. The word should mark out a certain topic.

A third-year student said:

"Learning issues must contain a keyword that makes it clear what the topic is that should be studied. Then you are able to search in the index of a book for this keyword, otherwise you start studying without knowing where you can start your searching."

In the third and fourth years a keyword is mentioned by $20 \%$ and $29 \%$ of all students respectively and is less frequently referred to in the first (14\%) and second years $(13 \%)$.

It seems, however, that a keyword alone does not provide sufficient information to make a learning issue complete and useful for individual study. For example, when the keyword is 'metabolism', it is not difficult to find this word in the index of several medical books, but it is not yet useful as a learning issue because it is defined too broadly. So it is obvious that the existence of a keyword or headword is not the only important characteristic.

\section{Conciseness}

The second important category is the concise description of the learning issue generated. The students gave many slightly different characteristics that were finally classified in this category. Examples that the students gave were 'clearly described' or 'briefly and to the point,' 'concise' or 'demarcates the literature'. In summary, this 
category represents the extent to which a learning issue describes concisely which aspects of a certain topic should be studied.

A second-year student said:

"It is important that a learning issue is clearly described in such a way that it marks out an area of a topic. For example: what is the function of the kidneys in the process of metabolism?"

Conciseness is the most frequent characteristics in all years and therefore uniformly the most essential component of a useful learning issue. In the first year it seems especially important: more than $50 \%$ mentioned this characteristic. In later years of training this varies from $34 \%$ in the second year, $39 \%$ in the third year to $45 \%$ in the fourth year. In contrast, a learning issue is not useful when it is vague and global. Many students mentioned vagueness as an important characteristic of a learning issue that is useless.

\section{A second-year student said:}

"Sometimes we generate the learning issues very hastily after the discussion in the tutorial group. It happens that you start your individual study and it turns out that the content of the learning issue contains such a broad domain that you must study almost a whole book to answer it. For example; study the pathology of the lungs."

The example described above shows that although the topic or area of study is clear, the learning issue does not indicate which part of the topic should be studied. The learning issue does not provide students with a tool indicating the direction and extent of study that must be undertaken. On the other hand, students mentioned that a learning issue should not be too specific. In other words, the literature to be studied to find an answer to the particular learning issue is too narrow.

\section{A first-year student said:}

"It occurs that we have generated a learning issue that is so specific that it can be answered with yes or no. That is not a problem as long as it was meant to be a small learning issue covering something we did not exactly know or had forgotten. It is a problem when the learning issue should lead to more individual study than only a yes or no answer." 


\section{Chapter 4}

\section{Unambiguousness}

The third important category of a useful learning issue is its unambiguousness and about $11 \%$ of the students in each year of training mentioned this as an essential characteristic of training. This means that a learning issue must be described in such a way that all members in the tutorial group interpreted the content of the learning issue in the same way.

A fourth-year student said:

"Sometimes we come back in the tutorial group and it appears that some of us hove understood the content of the learning issue in a different way from others and as a consequence we have studied things in the wrong context. This happens, for example, with a learning issue like: what is the matter with the man in the case we discussed."

\section{Discussion}

The first aim of this study was to describe the essential characteristics of useful learning issues. The results showed that most students did answer the free-response questions about the most essential characteristic. From the description of each category it becomes clear that the characteristics of a useful student-generated learning issue do not exclude each another. Therefore it seems possible to create a definition of a learning issue that contains all the characteristics that students reported.

The definition is:

A useful learning issue contains a kerword that demarcates the content of a certain topic to be studied, is formulated concisely and is unambiguous for all members of the tutorial group.

This definition can be helpful in the tutorial group. Tutors and students can be trained to generate and evaluate the learning issues generated on their usefulness for individual study on the basis of this definition.

The second question was about the importance of the characteristics in each year of training. There were minor differences in students' opinion of the most important characteristics between the years of training. Beginning students think it is more important that learning issues are formulated concisely, whereas students in later years stress the importance of a keyword. This may be because in the third and 
fourth years, students more often generate brief leaming issues and study according to 'the magic five' as a student put it; that is, the sequence of pathology, symptoms, diagnoses, therapy and prognoses. An alternative explanation for these differences is that in later years students are better able to determine on their own what is important for their individual study and in their opinion, a keyword provides enough direction for their individual study and the concise description of the learning issue is less important.

Two remarks should be made. First, although the definition might be helpful, it is important to mention that the quality of a learning issue will depend on many factors. The quality of the preceding discussion in the tutorial group is of great importance. When a discussion was very productive, this will result in wellgenerated learning issues and as a consequence the students will be better motivated to search for answers on the problems discussed. This illustrates that the learning issues generated are always a result, a final product, of the preceding discussion. Learning issues should always be seen as a result of a discussion in which students activate their prior knowledge (Schmidt, 1983). Second, it is not clear whether students filled in the questions reflecting how they actually generate learning issues, or whether they simply mentioned characteristics which they think are important. Probably it is a combination of both. Further research should be conducted to investigate whether variability in the quality of learning issues is reflected in subsequent individual study activities. The characteristics found in this study may facilitate the definition of the quality of learning issues. 


\section{References}

Barrows. II S. (1985). How to design a problem-based curriculum for the preclinical years. New York: Springer Publishing Company.

Barrows. II.S., \& Tamblyn. R.M. (1980). Problem-based learning. An approach to midicul education. New York: Springer Publishing Company.

Blumberg. P.. Michael. J.A.. \& Zeitz. H. (1990). Roles of student-generated learning behaviours in problem-based learning, Teaching and Learning in Medicine, 2. 149-154.

Dolmans, D.H.J.M., Schmidt, H.G., \& Gijselaers, H.G. (1995). The relationship between student-generated learning issues and self-study in problem-based learning, Instructional Science, 22, 251-267.

Schmidt, H.G. (1983). Problem-based learning: rationale and description, Medical Education, 17, 11-16.

Walton, H.J., \& Matthews. M.B. (1989). Essentials of problem-based learning. Medical Education, 23, 542-558. 


\title{
5
}

\section{The impact of student-generated learning issues on individual study time and academic achievement ${ }^{1}$}

\begin{abstract}
The aim of this study was twofold. The first question concerns the way students make use of the learning issues they generate (i.e., as strict guidelines or as global guidelines) and whether this changes across years of training. The second question concerned the relation between the way students make use of the learning issues and the time spent on individual study and achievement on two tests of knowledge. Subjects were all medical students (response rate $=69 \%$ ), from the problem-based curriculum, at the Maastricht University. A questionnaire was developed, containing seven items that measured to what extent students study strictly according to the student-generated learning issues and six items that measured to what extent students study beyond the student-generated learning issues. The questionnaire also contained one question in which students had to estimate the mean time spent on
\end{abstract}

Accepted for publication in Medical Education

M.M. van den Hurk, H.A.P. Wolfhagen, D.H.J.M. Dolmans and C.P.M. van der Vleuten

This article is also presented at the Annual Meeting of the American Educational Research Association in San Diego, April 13-17, 1998 (ERIC Document Reproduction Service No. TM 09729) 


\section{Chapter 5}

individual study. Achievement was measured by two forms of tests of knowledge, a block test assessing course content and a progress test assessing long-term functional knowledge. Results showed that students in the first year study strictly according to the content of the learning issues whereas students in later years studied more according to their own learning needs and interests. In addition, students who tend to study beyond the generated learning issues, spent more time on individual study and achieved better on both tests. It is concluded that students in a problem-based curriculum seem to become better self-directed learners during the years of training.

\section{Introduction}

In problem-based learning (PBL) students are encouraged to take substantial responsibility for their own learning. Independent and active learning is stimulated by discussing problems in small groups (Barrows \& Tamblyn, 1980). A problem consists of a description of a set of phenomena needing some kind of explanation. The discussion provides unanswered questions which subsequently serve as a guide for independent and self-directed learning (Schmidt, 1983). These questions are called student-generated leaming issues and are described by Blumberg, Michael, and Zeitz (1990) as factual or conceptual topics that each group decides must be better understood in order to analyse adequately the problem under discussion. Student-generated learning issues are an essential starting point for students' individual study and it is assumed that they play an important role in students" development of self-directed learning (Walton \& Matthews, 1989). According to Knowles (1975), self-directed leaming can be seen as a process in which individuals take the initiative with or without the help of others in diagnosing their learning needs, formulating learning goals, identifying human and material resources, choosing and implementing appropriate learning strategies and evaluating learning outcomes.

Some evidence for self-directing learning behaviour in PBL was found in a study by Blumberg and Michael (1992). They found that PBL-students used more resource materials than students in a conventional curriculum. Similarly, in a study at selfdirected learning skills of first year students in a PBL curriculum, Dwyer (1993) found that students at the end of the first year were feeling very much encouraged to identify learning needs and were more motivated to identify resources, compared to 
the beginning of the year. Ryan (1993) studied students' perceptions about their selfdirected learning skills. Students who were enrolled in a course which implemented problem-based learning filled in a questionnaire. The students seem to change their perception of the importance of self-directed learning. At the end of the year they had a more positive perception of their ability as self-directed leamers. So, it seems that when students are responsible for their own learning, they acquire autonomous leaming skills and learn to be better self-directed learners as they progress through their studies. In PBL student-generated learning issues play an important role in this process. In a study by Dolmans and Schmidt (1994), indirect evidence was found for this relationship. They focussed on the extent to which various elements of a problem-based curriculum influence students' decisions as to what to study. It was found that not only student-generated learning issues, but also other elements might have an impact on students' study decisions. These elements were literature cited in the reference list, content covered in lectures and tests. The influence of these elements tended to decrease over the four curriculum years. The influence of generated learning issues, on the contrary, tended to increase over the four years. It was concluded that students in a problem-based curriculum become more accomplished self-directed learners.

The extent to which students use the learning issues to definc the content of individual study is a process that can differ between students. Because PBL-students are highly responsible for their own learning, first-year and second-year students, who are not yet experienced self-directed learners, are consequently expected to rely more strongly on the learning issues formulated. With more seniority, students are expected to become better self-directed learners. This would imply that they are better able to identify their needs and to follow their own interests during their individual study.

Thus, it is expected that students in a problem-based curriculum in the first curriculum years will use learning issues step by step as strict guidelines to study the literature, whereas in later years they will use learning issues as global guidelines that fit their individual needs and interests better. The aim of this study was, first of all, to test this hypothesis and to find out whether there are differences between the years of training. If students, in the higher curriculum years, show increased use of learning issues as global guidelines and rely more on their own needs and interests, this might indicate that students become better self-directed learners.

A follow-up question addressed in this study was whether students who used learning issues more as global guidelines that fit their personal needs and interest, 


\section{Chapter 5}

would spend more time on individual study. In a problem-based curriculum, scheduled activities (tutorial groups, lectures, skills training, etcetera) are kept at a minimum per week to provide ample time for individual study (Gijselaers \& Schmidt, 1995). It was expected that students who studied beyond the learning issues generated, would spend more time on individual study. In addition, it was expected students with this learning approach would achieve better on tests. The examination system in a problem-based curriculum, such as the one under investigation, is aimed at rewarding extra learning activities during individual study and is aimed at avoiding test-driven study behaviour (Van der Vleuten, Verwijnen, \& Wijnen, 1996).

In summary, two questions are dealt with in this study. First, in which way do students make use of the generated learning issues (i.e., as strict guidelines or as global guidelines) and is there a difference according to year of training? Second, how does the use of generated learning issues relate to time spent on individual study and achievement on tests of knowledge?

\section{Method}

\section{Materials}

The study was conducted at the problem-based Medical School of the Maastricht Iniversity in the Netherlands, during the academic year 1995-1996. Prior to the construction of a questionnaire, 12 students were interviewed to gain more insight into whether and to what extent learning issues play a role during individual study. Based on these responses a questionnaire was developed. In this questionnaire seven items assessed the extent to which students study strictly according to the studentgenerated learning issues (i.e., learning issue restrictive approach) and six items measured the extent to which students study beyond the student-generated leaming issues (i.e., learning issue broadening approach). The first dimension (learning issue restrictive approach) reflects the use of learning issues as items that need to be answered step by step. The second dimension (learning issue broadening approach) reflects the extent to which students follow their own interest and their individual learning needs. The items of both dimensions are shown in Table 5.1. Students were asked to give their opinion on each item using a 5-point Likert scale ranging from (1) totally disagree to (5) totally agree. 
To assess construct validity of the two dimensions, a confirmatory factor analyses was performed (Arbuckle, 1997). The results showed a chi-square value of 217.75 ( $\mathrm{df}=64, \mathrm{~N}=479$ ), $p<0.001$, an adjusted goodness-of-fit index (AGFI) of 0.89 and a root mean square residual (RMSR) of 0.06 . The constraints as defined by Saris and Stronkhorst (1984) are met, such that the data are assumed to fit the two dimensions reasonably.

Further, the questionnaire contained one additional question in which students had to estimate the mean time they spent on individual study per week. A study by van Til, van der Vleuten and van Berkel (1997) showed that this method provides a reasonably reliable indicator of time spent on individual study.

Academic achievement was measured by using the scores on two different forms of tests. The first type was the block-test. In general the block-test, administered after each block, reflects the content of the foregoing block of six weeks. The major goal is to assess students' knowledge about the block contents and to provide the students with information on their achievement in relation to the course objectives. Each test is composed of 160 to 190 questions in the true/false format with an 'I don 't know' option (the question-mark option). Students are required to complete the block-test immediately after the end of each six-week block. A correct answer scores plus one, with an incorrect answer scoring minus one. The question mark scores zero. The overall score is the correct minus incorrect score and is expressed on a percentage scale. The other test is the progress test. All students of every year of training are required to take the progress test, a comprehensive test at graduate level, sampled from the total body of medical knowledge, four times a year (Van der Vleuten et al., 1996). Students cannot prepare themselves for the progress test and it therefore rewards the individual non-test-directed study activities of students. Each test consists of approximately 250 true/false items, with a question mark option, with scores expressed similarly to the block-test. 
Table 5.1. Seven items of the questionnaire measuring the learning issue restrictive approach and six items the learning issue broadening approach.

Items of dimension "leaming issue restrictive"

During my individual study I use learning issues as a...

- guideline to determine what literature I'm going to study

- check to see if the literature I have studied covers the content

- guideline to determine to what depth I must study certain topics

- guideline to mark out the subject matter

- guideline to study literature step-by-step

- guideline to distinguish main topics and side topics

During individual study I am guided by...

- the learning issues generated in the tutorial group

Items of dimension "learning issue broadening"

- When I am not attending the tutorial group meeting, I formulate my own learning issues

- I often formulate my own learning issues

- I choose literature on the basis of my interests, regardless of whether it is important for the blockcontent

- I study more broadly than what is only necessary to answer the learning issues

- When my individual study is restricted to the learning issues, I am afraid I will have gaps in my knowledge

- During my individual study I always try to integrate different topics

\section{Procedure}

The questionnaire was administered to all students of the first four years of training (the Maastricht programme is a 6-year training programme), at the end of the academic year 1995-96.

For each student a mean score was computed across the items measuring both dimensions (i.e.. leaming issue restrictive approach and learning issue broadening approach). To facilitate the interpretation of the data, the mean scores were categorized into three groups: the lowest group (score lower than 3), a middle group (score between 3 and 4) and the highest group (score higher than 4). For each group the mean time spent on individual study was calculated. Block-test scores were 
transformed into Z-scores per year and averaged across all seven tests of that year. The same procedure was followed with scores from all four progress tests in each year of training.

Differences between students' scores in each dimension on the hours spent on individual study and the test-score were analysed using ANCOVA with years of training as a covariate. Specific differences across the years of training were analysed with post-hoc analyses, using the Scheffe's $F$-test.

\section{Results}

In total 479 students filled in the questionnaire (response 69\%). In the first year the response rate was $74 \%(n=156)$, in the second year $72 \%(n=149)$, in the third year $72 \%(n=101)$ and $55 \%(n=73)$ in the fourth year.

Results in Table 5.2 show that the score on the first dimension (learning issue restrictive approach) was highest among first year students and lowest in the third and fourth year. These scores differ significantly $[F(3,468)=7.19, p<.0001]$, that is, the mean score of the first-year students differs significantly from those of the third and the fourth-year students.

Table 5.2. Mean scores on the dimensions (Mean), standard deviations (SD), total number of students $(\mathrm{N})$ and per year.

\begin{tabular}{|c|c|c|c|c|c|c|}
\hline & \multicolumn{3}{|c|}{$\begin{array}{l}\text { Learning issue restrictive } \\
\text { approach }\end{array}$} & \multicolumn{3}{|c|}{$\begin{array}{c}\text { Learning issue broadening } \\
\text { approach }\end{array}$} \\
\hline & Mean & $\mathrm{SD}$ & $\mathrm{N}$ & Mean & $\mathrm{SD}$ & $N$ \\
\hline Year 1 & 3.7 & 0.6 & 151 & 3.1 & 0.6 & 151 \\
\hline Year 2 & 3.6 & 0.6 & 145 & 3.4 & 0.6 & 144 \\
\hline Year 3 & 3.4 & 0.7 & 101 & 3.4 & 0.8 & 101 \\
\hline Year 4 & 3.4 & 0.7 & 74 & 3.5 & 0.7 & 74 \\
\hline Total & 3.6 & 0.7 & 471 & 3.3 & 0.7 & 470 \\
\hline
\end{tabular}


Table 5.2 also shows that for the second dimension (i.e., leaming issue broadening approach) students score lowest in the first year and highest in the fourth year. The scores between years differ significantly on this dimension $[F(3,467)=5.81, p<$ .0011 . that is. the first-year students differ significantly from the second, third and fourth-year students.

Table 5.3. Mean hours spent on individual study (Mean), standard deviation (SD), number of students in each group (N) for both dimensions (learning issue restrictive approach and learning issue broadening approach), split up for students scoring low ( $<3)$, middle (3-4), and high $(>4)$ on each dimension.

Learning issue restrictive approach

\begin{tabular}{|c|c|c|c|c|c|c|c|c|c|}
\hline & \multicolumn{3}{|c|}{ Low } & \multicolumn{3}{|c|}{ Middle } & \multicolumn{3}{|c|}{ High } \\
\hline & Mean & $\mathrm{SD}$ & $\mathrm{N}$ & Mean & $\mathrm{SD}$ & $\mathrm{N}$ & Mean & $\mathrm{SD}$ & $\mathrm{N}$ \\
\hline Year I & 14 & 6 & 13 & 15 & 8 & 59 & 16 & 6 & 53 \\
\hline Year 2 & 22 & 6 & 15 & 18 & 7 & 58 & 19 & 6 & 38 \\
\hline Year 3 & 16 & 8 & 21 & 16 & 8 & 47 & 20 & 8 & 19 \\
\hline Year 4 & 20 & 8 & 16 & 18 & 6 & 32 & 17 & 7 & 16 \\
\hline Total & 18 & 8 & 65 & 17 & 7 & 196 & 18 & 7 & 126 \\
\hline
\end{tabular}

Learning issue broadening approach

\begin{tabular}{|c|c|c|c|c|c|c|c|c|c|}
\hline & \multicolumn{3}{|c|}{ Low } & \multicolumn{3}{|c|}{ Middle } & \multicolumn{3}{|c|}{ High } \\
\hline & Mean & $\mathrm{SD}$ & $\mathrm{N}$ & Mean & SD & $\mathrm{N}$ & Mean & SD & $\mathrm{N}$ \\
\hline Year 1 & 14 & 6 & 39 & 16 & 8 & 68 & 19 & 9 & 18 \\
\hline Year 2 & 16 & 6 & 26 & 18 & 7 & 64 & 24 & 8 & 22 \\
\hline Year 3 & 15 & 5 & 25 & 18 & 9 & 41 & 18 & 8 & 21 \\
\hline Year 4 & 14 & 9 & 17 & 19 & 6 & 34 & 20 & 8 & 21 \\
\hline Total & 15 & 6 & 107 & 18 & 7 & 207 & 20 & 9 & 82 \\
\hline
\end{tabular}


Table 5.3 gives the mean time spent on individual study for three groups; students scoring in the low, middle and high ranges on each dimension. The three groups in the dimension "learning issue restrictive" do not differ significantly on the hours spent on individual study $[F(2,385)=.90, p>.40]$. For the dimension "learning issue broadening" groups differ significantly in hours spent on individual study $[F(2,384)=10.80, p<.001]$. These differences cannot be explained by years of training $[F(1,378)=1.38, p>.24]$. In all years the students with the highest score on this dimension reported the most time spent on individual study and students with the lowest score on this dimension reported the least time. Tables 5.4 and 5.5 contain the mean block-test and progress-test scores for each group in each dimension. Table 5.4 indicates that groups in the first dimension (i.e., learning issue restrictive approach) differ in their block-test scores.

A trend is shown that the more students study strictly according to the learning issues, the lower their score on the block-test. However, these differences are not significant $[F(2,464)=2.20, p>.11]$. The groups categorized on the second dimension (learning issue broadening approach) differ significantly on the block-test $[F(2,465)=5.81, p<.001]$. No significant effect for years of training $[F(2,465)=$ $.10, p>.74]$ was found. The scores on the block-test are higher when students have higher scores on the dimension. In other words, the more students study by going beyond the learning issues, the higher their score on the block-test.

In Table 5.5 the results for the progress test are shown, indicating that the three groups specified in the first dimension (i.e., learning issue restrictive approach) differ on the scores on the progress test. 


\section{Chapter 5}

Table 5.4. Mean Z-scores on block-test (Mean), standard deviation (SD), number of students in each group (N) for both dimensions (i.e., learning issue restrictive approach and learning issue broadening approach). split up for students scoring low $(<3)$, middle $(3-4)$, and high $(>4)$ on each dimension.

Learning issue restrictive approach

\begin{tabular}{|c|c|c|c|c|c|c|c|c|c|}
\hline & \multicolumn{3}{|c|}{ Low } & \multicolumn{3}{|c|}{ Middle } & \multicolumn{3}{|c|}{ High } \\
\hline & Mean & SD & $\mathrm{N}$ & Mean & SD & $\mathrm{N}$ & Mean & SD & $\mathrm{N}$ \\
\hline Year 1 & 0.09 & 0.8 & 17 & 0.14 & 1.0 & 74 & -0.18 & 1.0 & 59 \\
\hline Year 2 & 0.39 & 0.4 & 19 & 0.05 & 0.9 & 71 & -0.23 & 1.0 & 42 \\
\hline Year 3 & -0.21 & 1.0 & 28 & 0.08 & 0.9 & 57 & 0.03 & 1.2 & 21 \\
\hline Year 4 & 0.24 & 1.1 & 19 & -0.13 & 0.9 & 39 & -0.10 & 0.7 & 19 \\
\hline Total & 0.13 & 1.1 & 83 & 0.04 & 0.9 & 241 & -0.13 & 1.0 & 141 \\
\hline
\end{tabular}

Learning issue broadening approach

\begin{tabular}{|c|c|c|c|c|c|c|c|c|c|}
\hline & \multicolumn{3}{|c|}{ Low } & \multicolumn{3}{|c|}{ Middle } & \multicolumn{3}{|c|}{ High } \\
\hline & Mean & SD & $N$ & Mean & $\mathrm{SD}$ & $\mathrm{N}$ & Mean & SD & $\mathrm{N}$ \\
\hline Year 1 & -0.27 & 1.0 & 45 & 0.13 & 0.9 & 84 & 0.15 & 1.0 & 17 \\
\hline Year 2 & -0.30 & 0.8 & 29 & -0.02 & 1.0 & 75 & 0.33 & 1.0 & 29 \\
\hline Year 3 & -0.06 & 1.0 & 31 & 0.06 & 1.0 & 47 & -0.03 & 1.0 & 27 \\
\hline Year 4 & -0.37 & 0.9 & 19 & 0.08 & 0.9 & 37 & 0.16 & 1.1 & 24 \\
\hline Total & -0.24 & 0.9 & 124 & 0.06 & 0.9 & 243 & 0.16 & 1.0 & 97 \\
\hline
\end{tabular}

These differences are significant $[F(2,463)=5.60, p<.001]$. No significant effect for years of training $[F(2,463)=.51, p>.47]$ was found. Students who reported low on this dimension have higher scores on the test, whereas students who reported high on this dimension have low scores on the progress test. Groups in the second dimension (learning issue broadening approach) also differ significantly on the progress test $[F(2,465)=7.90, p<.001]$. There was no significant effect for years 
of training $[F(2,465)=.29, p>.59]$. Students who reported high on this dimension have also higher scores on the progress test compared to students who reported low.

Table 5.5. Mean Z-scores on progress-test (Mean), standard deviation (SD), number of students in each group $(N)$ for both dimensions (i.e., learning issue restrictive approach and learning issue broadening approach), split up for students scoring low (<3), middle (3-4), and high $(>4)$ on each dimension.

Learning issue restrictive approach

\begin{tabular}{|c|c|c|c|c|c|c|c|c|c|}
\hline & \multicolumn{3}{|c|}{ Low } & \multicolumn{3}{|c|}{ Middle } & \multicolumn{3}{|c|}{ High } \\
\hline & Mean & $\mathrm{SD}$ & $\mathrm{N}$ & Mean & SD & $\mathrm{N}$ & Mean & SD & $\mathrm{N}$ \\
\hline Year 1 & 0.17 & 0.8 & 17 & 0.02 & 1.0 & 74 & -0.03 & 0.9 & 59 \\
\hline Year 2 & 0.51 & 1.4 & 19 & -0.02 & 0.8 & 71 & -0.18 & 0.9 & 42 \\
\hline Year 3 & 0.08 & 1.0 & 28 & -0.05 & 0.8 & 57 & 0.53 & 1.2 & 22 \\
\hline Year 4 & 0.31 & 1.1 & 19 & -0.13 & 1.0 & 39 & -0.05 & 0.5 & 19 \\
\hline Total & 0.26 & 1.1 & 83 & -0.04 & 0.9 & 241 & 0.06 & 0.9 & 142 \\
\hline
\end{tabular}

Learning issue broadening approach

\begin{tabular}{|c|c|c|c|c|c|c|c|c|c|}
\hline & \multicolumn{3}{|c|}{ Low } & \multicolumn{3}{|c|}{ Middle } & \multicolumn{3}{|c|}{ High } \\
\hline & Mean & SD & $\mathrm{N}$ & Mean & SD & $\mathrm{N}$ & Mean & SD & $\mathrm{N}$ \\
\hline Year 1 & -0.12 & 0.8 & 45 & 0.06 & 1.0 & 84 & 0.06 & 1.3 & 17 \\
\hline Year 2 & -0.19 & 0.8 & 29 & -0.10 & 1.0 & 73 & 0.49 & 1.3 & 29 \\
\hline Year 3 & -0.07 & 0.8 & 33 & -0.03 & 0.8 & 47 & 0.16 & 1.1 & 27 \\
\hline Year 4 & -0.24 & 0.6 & 20 & 0.06 & 1.0 & 39 & 0.08 & 1.2 & 24 \\
\hline Total & -0.14 & 1.8 & 124 & -0.01 & 0.9 & 243 & 0.23 & 1.2 & 97 \\
\hline
\end{tabular}




\section{Discussion and conclusion}

The first aim of this study was to answer the question of to what extent students restrict themselves to the learning issues generated in the tutorial group and to what extent they go beyond the learning issues. The first conclusion of this study is that especially first-year students use learning issues in a different way from students in the senior years. First-year students confine themselves more strictly to the content of learning issues and use a more learning issue restrictive approach. This implies that they are answering them step by step, using them as a tool to demarcate the literature. In later years students study more according to their own learning needs and interests, use a more learning issue broadening approach, and study not only according to topics directly related to the learning issues generated. A possible explanation is that students in the first year are uncertain about what literature should be studied. Senior students probably feel better able to determine independently what to study, may have more knowledge about the vast number of information resources available, may have better information seeking skills, may be better at self-monitoring and may be more efficient about their time allocation. Thus, students seem to become better self-directed learners during the years of training. A theory of Vermunt (1995) states that when students are able to regulate their own learning process and when the instruction programme is not heavily externally regulated, there is no friction in the learning process of students. Perhaps students in later years need less external regulation and therefore are more likely to go beyond the leaming issues generated and are better able to regulate their own learning needs than first-year students.

However, two problems can bias the interpretation of the results. First, only half of the students in the fourth year did respond $(55 \%)$. It might be possible that the questionnaires have been completed by more motivated students, who might also be the ones who study widely and do better in tests. However, in the third year in which $72 \%$ of all students completed the questionnaire the results show a very similar pattern as to the fourth-year students. A second bias might be that data were not gathered longitudinally, due to which differences between years of training can still be explained by differences in student population across the years of training. Another explanation of the fact that students in later years study more beyond the learning issues might be that the quality of the student-generated learning issues decreases during years of training. In the interviews taken with three students in each year, students in the third and fourth year mentioned that the tutorial groups 
were sometimes less functional than in the first and second year. This could have a negative impact on the learning issues generated and students would then be forced to determine for themselves what is important to study. However, in the same interviews, students in each year reported that learning issues were an important starting point for individual study and were very useful to this end. Further research is needed to clarify this issue.

The second aim of this study was to explore the relation between the use of learning issues and the time spent on individual study and achievement. The results showed that students who go beyond the learning issues spend more time on individual study and also achieve better on tests of knowledge. It seems that when students are developing themselves as self-directed learners, in PBL this way of leaming will be rewarded. This is important because the "learning issue broadening" dimension does imply that these students focus on relevant issues and not on irrelevant oncs. otherwise they were unlikely to do better on tests of knowledge.

Thus, students do achieve better and might have a better understanding of the issues, when they study more than what is directly related to the learning issues. Therefore students must be stimulated to study beyond the learning issues and must develop the skills to be able to determine independently what relevant issues are for their individual study. Although a decrease over the years of training in the leaming issue restricted approach and an increase in the learning issue broadening approach might indicate that both approaches are likely to be inverse. However, both approaches can still be complementary in stead of inversely related becausc students can use a combination of both approaches. i.e. using learning issues as strict guidelines but also broadening their study.

An alternative explanation might be that students who go beyond the learning issues are more test-driven instead of being better aware of a certain lack in their medical knowledge. They spend more time on studying certain topics for hetter understanding of the materials that are tested instead of satisfying their own learning needs. Pure test-driven learning could be rewarded by the block-test but not by the progress test. However, the effects were similar for both tests. A remedial approach, checking blank spots and studying systematically, might, however, be considered as an important self-directed learning skill. 
(hopler 5

\section{References}

Arbuckle. J.L. (1997). Amos users' guide; version 3.6. Chicago: Smallwaters Corporation.

Barrows. H.S., \& Tamblyn, R.M. (1980). Problem-based learning. An approach to medical education. New York: Springer Publishing Company.

Blumberg, P., \& Michael, J.A. (1992). Development of self-directed learning behaviours in a partially teacher-directed problem-based learning curriculum. Teaching and Learning in Medicine, 4, 3-8.

Blumberg, P., Michael, J.A., \& Zeitz, H. (1990). Roles of student-generated learning issues in problem-based learning. Teaching and Learning in Medicine, 2, 149154.

Dolmans, D.H.J.M., \& Schmidt, H.G. (1994). What drives the student in problembased learning? Medical Education, 28, 372-380.

Dwyer, J. (1993). Predicting self-directed learning readiness: a problem or not? In G. Ryan (Ed.), Research and development in problem-based learning. Sydney: Macarthur.

Gijselaers, W.H., \& Schmidt, H.G. (1995). Effects of quantity of instruction on time spent on learning and achievement. Educational Research and Evaluation, I, 183-201.

Knowles, M.S. (1975). Self-directed learning: a guide for learners and teachers. New York: Cambridge Books.

Ryan, G. (1993). Student perceptions about self-directed learning in a professional course implementing problem-based learning. Studies in Higher Education, 18, 53-63.

Saris, W.E., \& Stronkhorst, L.H. (1984). Causal modelling in non-experimental research. Amsterdam: Sociometric Research Foundation. 
Schmidt, H.G. (1983). Problem-based learning: rationale and description, Medical Education, 17, 11-16.

Van Til, C.T., Van der Vleuten, C.P.M., \& Van Berkel, H.J.M. (1997). Invloed van regelmaat van studeren binnen PGO op de studieresultaten van studenten [Influence of regularity of studying in a problem-based curriculum on students' achievement]. In J.A. Smal (ed.), GOC-proceedings. Houten: Bohn Stafleu Van Loghum.

Van der Vleuten, C.P.M., Verwijnen, G.M., \& Wijnen, W.H.F.W. (1996). Fifteen years of experience with progress-testing in a problem-based curriculum. Medical Teacher, 18, 103-109.

Vermunt, J.D.H.M. (1995). Process-oriented instruction in learning and thinking strategies. European Journal of Psychology and Education, 10, 325-349.

Walton, H.J., \& Matthews. M.B. (1989). Essentials of problem-based learning. Medical Education, 23, 542-558. 


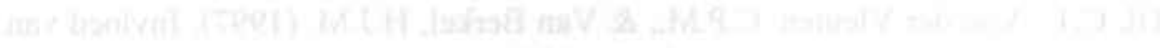

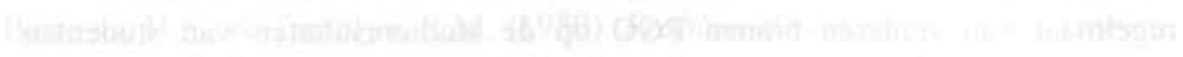

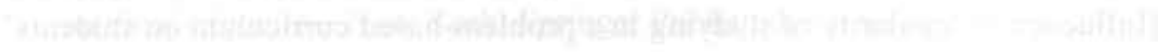

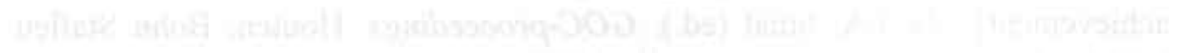




\title{
Impact of individual study on tutorial group discussion ${ }^{1}$
}

\begin{abstract}
This study focuses on this relationship between individual study and group discussion. In a problem-based curriculum it is expected that the way students prepare themselves during individual study (i.e., search and prepare the literature) will influence the quality of the reporting phase. The purpose is to investigate whether searching for different literature resources and preparing the literature (by making summaries to explain the literature) affects the quality of the reporting phase. A 23-item questionnaire was developed, reflecting two factors of the search phase and one factor of the preparation phase of the individual study. Two factors (breadth and depth of the discussion) reflected the reporting phase. Participants were first-year students $(N=195,90 \%)$ at the Medical School of the Maastricht University in the Netherlands during the academic year 1997-1998. The results of the regression analyses showed that the search phase and the preparation phase explained $29 \%$ of the variance of the breadth and $38 \%$ of the depth of the reporting phase. It was concluded that searching different literature resources has a small and
\end{abstract}

1 Published in Teaching and Learning in Medicine. 11. 4, 196-201, 1999

M.M. van den Hurk, D.H.J.M. Dolmans, H.A.P. Wolfhagen, A.M.M. Muijgijens and C.P.M. van der Vleuten 
negative impact on the quality of the reporting phase. However, preparing extensively for the next tutorial meeting is very important for especially the depth of the reporting phase. Therefore, when new knowledge must be integrated in the tutorial group, students must be taught to prepare themselves by making summaries that are useful and effective during the discussion.

\section{Introduction}

A problem-based curriculum emphasizes the development of self-regulated leaming skills. Therefore, students should be actively involved, rather than be passive recipients of information (Zimmerman \& Schunk, 1989). The process of learning within problem-based framework can be outlined as follows (see Figure 6.1). First, students are stimulated to discuss a problem in the tutorial group (phase 1).

Figure 6.1. Components of the learning process in a problem-based curriculum.

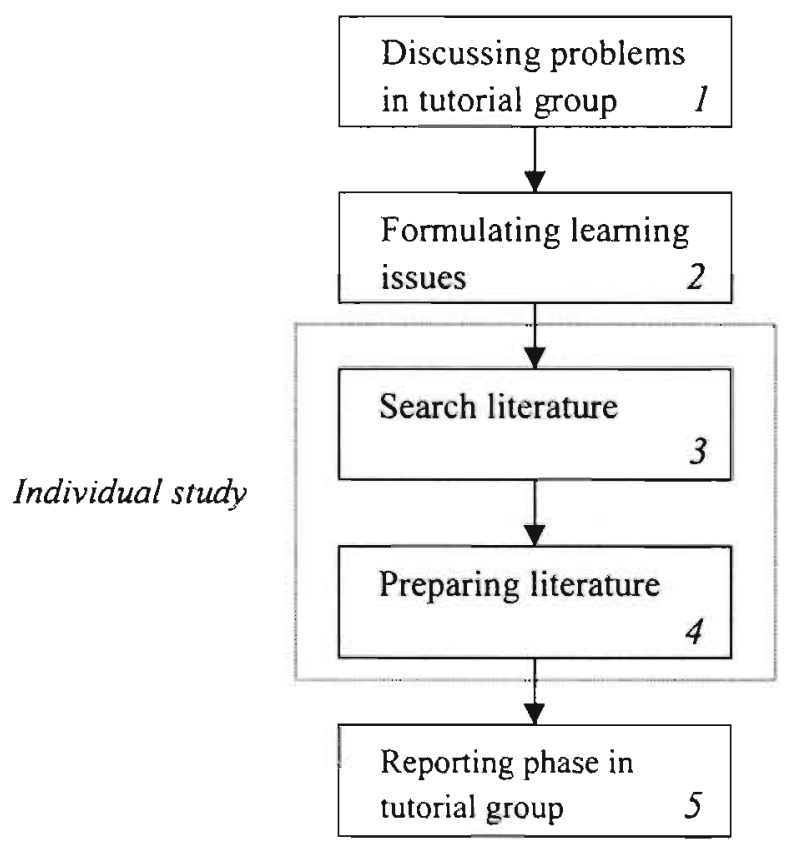


A problem consists of a description of a set of phenomena needing some kind of explanation (Schmidt, 1983). However, during the discussion some questions remain unanswered. These questions serve as learning issues (phase 2). Phases 3 and 4 are related to the students' individual study. Students actively search for literature that seems relevant regarding the learning issues (phase 3). Subsequently, students prepare the literature in order to explain their findings during the reporting phase to other students of the tutorial group (phase 4). Finally, in phase 5, when the group meets again in the reporting phase, students check whether the results of individual study enable them to understand and explain the problem (Norman \& Schmidt, 1992). This study focuses on the learning processes in phases 3 to 5.

In the search phase, students are supposed to orient themselves on as many different learning resources as possible. This process of searching should be considered as a preparation of actual studying by means of inspecting the available resources like textbooks, the Internet and journals. An assumption of a problem-based curriculum is that students must develop skills to manage differences or even contradictions in the literature. Moreover, in a tutorial group in which students do not consult a diversity of information in relation to the learning issues generated, exchange of different findings in literature during the reporting phase will not take place. Therefore, the discussion will be less broad and probably more shallow. A problembased curriculum emphasizes that students learn to compare and search different resources during individual study. The extent to which students practice this process of consulting different resources, is often seen as an indicator of self-directed learning. Rankin (1992) investigated whether students in a problem-based curriculum become self-directed learners. The study involving four medical schools, three problem-based and one conventional, found that students in a problem-based curriculum made greater use of the library, made greater use of self-selected (as opposed to faculty-selected) reading materials, and felt more competent in independent information seeking skills. These findings are supported by other studies (Albanese \& Mitchell, 1993; Blumberg \& Michael, 1992; Nolte, 1989; Saunders, Northup, \& Mennin, 1985).

During the process of searching, student-generated learning issues are assumed to play an important role (Walton \& Mathews, 1989). Dolmans and Schmidt (1994) explored to what extent student-generated learning issues influenced students' individual study and what other curriculum elements (i.e., a literature reference list, tests, and lectures) play a role in students' individual study. Based on the results of interviews and a questionnaire, Dolmans and Schmidt concluded that learning issues 
are the main starting point for students' individual study. However, first-year students also rely on other elements. such as literature reference list. and the tutor suggestions. The influence of these elements tends to decrease over the four curriculum years whereas the influence of the learning issues tends to increase. So. students differ in the extent to which they are driven by learning issues.

Another aspect influencing the reporting in the tutorial group is related to the preparation of the literature in order to explain it to others. Research in small group leaming show that students will learn most when they give explanations (King; 1992: Webb, 1992; Webb, Troper, \& Fall, 1995). According to Webb and collegues (1995). the process of giving explanations may encourage students to clarify or roorganize knowledge, recognize and fill in gaps in knowledge and construct elaborate conceptualizations. In problem-based learning students are expected to give explanations to each other and clarify the phenomena that underlie the problem. Students must prepare this during their individual study by questioning what is relevant in the text, by making summaries, notes, translating the literature in their own words, and by making selections in the text. In other words, students should engage in an explanation-oriented approach. Research shows that eliciting selfexplanations facilitates the integration of new information into existing knowledge (Chi, Bassok, Lewis, Reimann, \& Glaser, 1989; Chi, DeLeeuw, Chiu, \& La Vancher, 1994; Coleman, 1998; King, 1992). For example, Chi and colleagues (1994) compared two groups of students. In the first group, students were asked to self-explain each line of a passage in a text. In the second group, students were only asked read the text twice. The students who generated self-explanations learned with greater understanding than did the students who only read the text. These findings suggest that students who learn in an explanation-oriented way will be better understand concepts and, therefore, will probably be better able to explain more different concepts with a deeper understanding.

Thus, the aim of the present study is to shed light on the extent to which students' learning issues and the extensiveness of their search of the literature will affect positively the breadth and depth of the discussion in the tutorial group. It is assumed that an explanation-oriented preparation of the literature will affect positively the breadth and depth of the discussion of the tutorial group. 


\section{Method}

\section{Participants}

Participants were all the first-year students $(\mathrm{N}=195)$ at the Medical School of the Maastricht University during the academic year 1997-1998. One hundred and seventy-five students responded (90\%) spread over 23 tutorial groups. In each tutorial group nine students participated and the number of students completing the questionnaire varied between six and nine students per tutorial group.

\section{Materials}

A questionnaire was developed containing 23 items reflecting the phases of the individual study (search and preparation), and the reporting phase. Two factors referred to the search phase: (1) "learning issue driven searching," indicating the use of learning issues when searching learning resources, (2) "extensiveness of searching," suggesting the extent to which students searched and compared different learning resources. One factor referred to the preparation phase: (3) "explanationoriented," indicating whether students studied the literature in order to explain the content to another student by making summaries and notes during studying. Two factors reflected the reporting phase: (4) "breadth of reporting," illustrating the extent to which a variety of literature resources were used during the reporting phase and (5) "depth of reporting," indicating the extent to which the newly learned information was integrated.

Five educational researchers with expertise in the field of problem-based learning and twelve first-year students were asked to judge a draft version of the questionnaire. They were asked to judge whether each question reflected one of the factors. Students were asked to give their opinion on each item using a 5-point Likert scale ranging from (1) totally disagree to (5) totally agree. The items of the questionnaire are shown in Table 6.1.

\section{Procedure}

Students were involved in a problem-based course called 'Attack and defence'. 'This course deals with infection and the working of the immune system. After working on two tasks, students were asked to fill out the questionnaire individually (at home). They were instructed to give answers that reflected their studying during the previous two weeks. 
Table 6.1. Questionnaire items for search, preparation and reporting phase.

\section{Search phase}

Learning issue driven searching (5 items)

When I start studying, I use the learning issues as a starting point to determine what literature I will search

During studying......

.....I always check the learning issues to determine whether I study deep enough

......'m particularly guided by the learning issues

....I use learning issues to see if the literature I have studied covers the content

.....I use learning issue as a guideline to study the literature step-by-step

Extensiveness of searching (4 items)

- When searching the literature, I try to judge different textbooks on their relevance for the subject to be studied

- When scarching the literature, I compare different literature about the same subject

- I spent a lot of time and effort on searching the literature before I start studying

- When searching the literature, I compare different literature about the same subject

\section{Preparation phase}

Explanation-oriented (6 items)

I prepare myself.......

.....such that I can explain the literature without the textbooks

.....such that I can clarify my point of view about theories

.....such that I can explain concepts in literature in my own words

.....such that I know what needs to be discussed in each learning issue

.....by making summaries of the literature

by making notes

\section{Reporting phase}

Breadth of discussion (4 items)

- Many different findings are discussed

- When someone finds something that is not directly related to the learning issues, it is explained to others

- The members of the group frequently question different aspects of the literature

- Contrasting literature is explained

Depth of discussion (4 items)

- During the discussion in the reporting, the new facts are explained and elaborated

- The discussion in the reporting contains much depth

- In using the newly learned knowledge, we question and clarify the phenomena which underlie the problem

- The discussion in the reporting is very useful in addition to what I study 


\section{Analyses}

Data were aggregated at the tutorial group level by computing mean scores across students for each tutorial group (23 groups). The mean score of each tutorial group was the unit of analysis in all statistical procedures. To assess the construct validity of the factors, first explorative factor analyses were conducted. Subsequently, confirmatory factor analyses were performed to investigate whether the model of five factors fitted the data (Arbuckle, 1997). The three factors from the search and preparation phases were not significantly correlated. The factors in the reporting phase (breadth and depth) correlated significantly $(\mathrm{r}=0.66 ; p<0.01)$.

The constraints, as defined by Saris and Stronkhorst (1984), provide an indication whether the model fits the data: A Chi-square value divided by the degrees of freedom lower than 3, a p-value larger than 0.00, an Adjusted Goodness of Fit Index (AGFI) larger than 0.80 and a Root Mean Square Residual (RMSR) lower than 0.07. The results showed a Chi-square value of $249.3(\mathrm{df}=179, \mathrm{~N}=23), p<0.001$, an AGFI of 0.61 and a RMSR of 0.04 . The constraints are satisfied for two out of four constraints, such that the data are assumed to fit the factors reasonably.

To test reliability, Cronbach's alpha was calculated for each factor using the mean score of the variables of each tutorial group. The results showed that the alpha of one factor was low, namely 0.53 (breadth of reporting). The alphas of the other factors varied between 0.64 and 0.80 . To assess the extent to which the factors in the search phase and preparation phases explain the variance in the breadth and depth of the reporting phase two univariate regression analyses were performed: the analyses were performed with breadth of reporting as the dependent variable, the second with depth of reporting as dependent variable.

\section{Results}

In Table 6.2 the mean score of each factor is shown. The factor with the lowest mean score is the extensiveness of searching learning resources $(M=2.8)$ and that with the highest score is depth of reporting $(M=3.4)$. 
Table 6.2. Mean scores on factors (Mean), standard deviation (SD), number of groups $(\mathrm{N})$.

\begin{tabular}{lccc}
\hline & Mean & SD & N \\
\hline Search phase & & & \\
Learning issue driven searching & 3.1 & 0.3 & 23 \\
Extensiveness of searching & 2.8 & 0.4 & 23 \\
\hline $\begin{array}{l}\text { Preparation phase } \\
\text { Explanation-oriented }\end{array}$ & 3.2 & 0.3 & 23 \\
\hline Reporting phase & & & \\
Breadth of discussion & 3.0 & 0.4 & 23 \\
Depth of discussion & 3.4 & 0.5 & 23 \\
\hline
\end{tabular}

To determine the extent to which the independent variables explain the variance in each dependent variable (breadth and depth of reporting), two univariate regression analyses were performed, with first, breadth of reporting as dependent variable and second depth of reporting. Results are presented in Table 6.3 . It shows that $29 \%$ of the variance in breadth of reporting is explained by the factors in the search and preparation phases. The betas show that the contribution to the variance is almost equal for the three factors (successively $0.25,0.27,0.21$ ). There were no significant contributions. 
Table 6.3. Regression weights $\left(R^{2}\right.$ and Beta), the $t$-value $(t)$ and the F-value $(F)$ with breadth and depth of reporting phase as dependent variables and the factors in preparation phase and searching phase as independent factors $(\mathrm{N}=23)$.

\begin{tabular}{lllll}
\hline & $\mathrm{R}^{2}$ & Beta & $\mathrm{t}$ & $\mathrm{F}$ \\
\hline
\end{tabular}

Dependent variable: Breadth

1. Searching phase

- Leaming issue driven $0.25 \quad 1.01$

- Extensiveness searching

$0.27 \quad 1.22$

2. Preparation phase

0.29

2.662

- Explanation-oriented

$0.21 \quad 0.79$

Dependent variable: Depth

1. Searching phase

- Learning issue driven

$0.18 \quad 0.77$

- Extensiveness searching

$-0.15-0.62$

2. Preparation phase

0.38

$3.923 *$

- Explanation-oriented

0.53

$2.08^{*}$

${ }^{*} p<0.05$

The lower part of Table 6.3 shows that $38 \%$ of the variance of the variable depth of reporting is explained by the search and preparation phases. Explanation-oriented (beta $=0.53$ ) is the most important and significant factor. The extensiveness of searching reveals a negative influence (beta $=-0.15$ ).

\section{Conclusions and discussion}

The question investigated was the degree to which students" self-reports of individual study in the search and preparation phases affected students' perceptions of the breadth and depth of group discussions in the reporting phase. The breadth of 
the reporting phase is defined as the extent to which different findings or topics in literature are exchanged. In a problem-based curriculum students conduct literature searches themselves, not only they learn to find necessary material independently, they also learn to manage, for example, contradictions in the literature. The results of this study show that when students search and compare different literature resources during their individual study, this will positively stimulate the breadth of the reporting phase. However, the mean score on this factor (i.e., extensiveness of searching) is rather low $(M=2.8)$. This indicates that students did not extensively search and compare different literature. An explanation for this low mean score is that participants were first-year students. One may assume that advanced students, who are more experienced learners, might search for more different learning resources. Advanced students have developed superior information seeking skills and it is likely that this will affect the breadth of the discussion. However, Cohen (1994) stated in a review article on small group learning that students who are experienced learners in collaborative work, are tended to limited exchange of information and explanation. It is argued that an open and broad exchange and elaborated discussion are always necessary for optimal conceptual learning. Future research should focus on how students develop skills in searching literature during the years of training in a problem-based setting and whether this stimulates the breadth of the discussion.

The results of this study also show a trend that preparing the literature for the next tutorial meeting does affect the breadth of the reporting phase (although not significantly). When students prepare the literature with the aim of explaining it to someone else, the breadth of the discussion will also be stimulated.

Concerning the second research question, the results show that when students in a tutorial group prepare themselves extensively for the next tutorial, that will affect the depth of the reporting phase. Preparation of the literature by making summaries, and studying in order to explain the content to each other seems crucial for stimulating the deeper understanding of the findings. Previous research in small group learning show that a deeper understanding and the construction of elaborated conceptualizations is promoted when students give and receive explanations during discussion. These findings suggest that this is affected by students explanationoriented way of preparing; they will be better understand concepts and, therefore, will probably be better able to explain concepts with a deeper understanding.

Conversely, when students search extensively for different literature, the reporting phase appears to be less deep (a non-significant trend). An explanation for this 
negative influence, may be that when students in a tutorial group have found different literature, the discussion needs to be very well-structured to reach a deeper understanding of the findings. Therefore, the discussion leader, who is a member of the group, has an important but difficult task to structure the discussion. Although students are trained to perform this role, it can sometimes be too difficult for firstyear students with only limited experience to lead a discussion, and as a result the reporting phase will yield a less deep understanding. Another explanation could be that the level of expertise of the tutor influenced the quality of the reporting. However, all tutors are members of the faculty with comparable levels of expertise about the block content in question.

When students start their individual study by searching literature with the learning issues generated, this seems to have both a positive effect on the breadth and depth of the reporting phase. Learning issues seem not only to serve as a main starting point for students" individual learning, but the learning issues also scem to structure and direct the discussion in the reporting phase.

In conclusion, the way students search and prepare the literature has an impact on the quality of the reporting phase. However, the most significant factor is the way students prepare the literature for the next tutorial meeting. This implicates for educational practice that, not only students must learn to give explanations during the discussion, they must also be taught how to develop skills to prepare for this during their individual study. For example, King (1995) developed an inquiry-based approach to facilitate critical thinking and explaining based on individual and group learning by students. Students are taught how to ask questions using a model of inquiry and how to apply it in cooperative-learning contexts, in individual learning and study settings. As follows, students develop skills to ask thoughtful questions of themselves and each other on what they read in their textbooks. hear in lectures, and encounter during discussions.

Finally, a limitation to this study is that all the measurements were student opinions. It would be an improvement if the dependent variable were measured independently of the independent variables. For example, instead of student opinion, trained observers could score the breadth and depth of the reporting phase. 


\section{Chapter 6}

\section{References}

Albancsc. M.A., \& Mitchell, S. (1993). Problem-based learning: a review of literature on its outcomes and implementation issues. Academic Medicine, 68, $52-81$.

Arbuckle. J.L. (1997). Amos users' guide; version 3.6. Chicago: Smallwaters Corporation.

Blumberg, P., \& Michael, J.A. (1992). Development of self-directed learning behaviours in a partially teacher-directed problem-based learning curriculum. Teaching and Learning in Medicine 4, 3-8.

Chi. M.T.H., Bassok, M., Lewis, M.W., Reimann, P., \& Glaser, R. (1989). Selfexplanations: How students study and use examples in learning to solve problems. Cognitive Science, 18, 145-182.

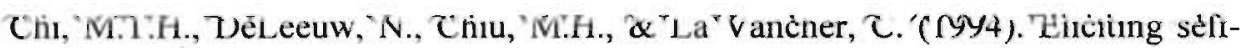
explanations improves understanding. Cognitive Science, 18, 439-477.

Cohen, E.G. (1994). Restructuring the classroom: Conditions for productive small groups. Review of Educational Research, 64, 1-35.

Coleman, E.B. (1998). Using explanatory knowledge during collaborative problem solving in science. The Journal of the Learning Sciences, 7, 387-427.

Dolmans, D.H.J.M., \& Schmidt, H.G. (1994). What drives the student in problembased learning? Medical Education, 28, 372-380.

King, A. (1992). Facilitating elaborative learning through guided student-generated questioning. Educational Psychologist, 27, 111-126.

King, A. (1995). Inquiring minds really do want to know: Using questioning to teach critical thinking. Teaching of Psychology, 22, 13-17. 
Nolte, J.A. (1989). Allocation of educational time by first year medical students in traditional and in partially problem-based curricula. In D.S. Dabney (Ed.), Proceedings of the Twenty-eighth Annual Conference on Research in Medical Education (pp. 35-39). Washington: Association of American Medical Colleges.

Norman, G.R., \& Schmidt, H.G. (1992). The psychological basis of problem-based learning: a review of the evidence. Academic Medicine, 67, 557-565.

Rankin, J.A. (1992). Problem-based medical education: effect on library use. Bulletin of Medical Library Associates, 80, 36-43.

Saris, W.E., \& Stronkhorst, L.H. (1984). Causal modelling in non-experimental research. Amsterdam: Sociometric Research Foundation.

Saunders, K., Northup, D.E.. \& Mennin, S.P. (1985). The library in a problem-based curriculum. In A. Kaufman (Ed.), Implementing problem-based medical education (pp. 291-314). New York: Springer Publishing Company.

Schmidt, H.G. (1983). Problem-based learning: rationale and description. Medical Education, 17, 11-16.

Walton, H.J., \& Matthews, M.B. (1989). Essentials of problem-based learning. Medical Education, 3, 542-58.

Webb, N.M. (1992). Testing a theoretical model of student interaction and learning in small groups. In R. Hertz-Lazarowitz \& N. Miller (Eds.), Interaction in cooperative groups: The theoretical anatomy of group learning (pp. 102-120). New York: Cambridge University Press.

Webb, N.M., Troper, J.D., \& Fall, R. (1995). Constructive activity and learning in collaborative groups. Journal of Educational Psychology. 87, 406-423.

Zimmerman, J.B., \& Schunk, D.H. (1989). Self-regulated learning and academic achievement. New York: Springer Publishing Company. 



\title{
Testing a causal model for learning in a problem-based curriculum ${ }^{1}$
}

\begin{abstract}
The aim of this study was to identify the relationship between elements that are important for the tutorial group process and the individual learning process in a problem-based curriculum. The variables under investigation were: Studentgenerated learning issues, individual learning process, reporting in the tutorial group and achievement. A questionnaire containing 22 items was developed. Dutu were collected in the first year $(N=195)$ of the Medical School of the Maastricht University in the Netherlands during the academic year 1997-1998. The data were analysed using a structural modelling approach. The results indicate that the model fitted the data well. The path coefficients were moderately high, particular between the explanation-oriented approach and the depth of the reporting in the tuturial group. High path coefficients were also found between the depth of the reporting and achievement. In sum, the model gives insight in how important variables ure related and it is recommended that data should be collected to test the model repeatedly.
\end{abstract}

\footnotetext{
This chapter is presented at the Annual Meeting of the American Educational Research Association in Montreal, Canada, April, 1999 (ERIC Document Reproduction Service No. TM 029730).
} 


\section{Introduction}

One of the most striking characteristics of problem-based learning (PBL) is that an important part of the learning process takes place in a small tutorial group. This small group learning as an educational format has certain advantages. For example, Webb, Troper. and Fall (1995) have shown that students, who leam in small groups. are stimulated to clarify or explain their ideas. They are more conscious of deficiencies in their knowledge and they develop more elaborate explanations for the problem at hand (Coles, 1985). Furthermore, students who discuss topics or try to solve a problem in a small group, establish actively new relations between concepts that they already know. In other words, as a result of the small-group discussion, students create a structure of deep and rich connections in their knowledge base. Gabbert, Johnson, and Johnson (1986) have shown that learning in small groups results in positive effects on student achievement and retention of information. They found that. on tasks which require the use of high-level reasoning strategies, individuals who learned in a cooperative setting showed a better achievement. Webb (1985) has also demonstrated the relationship between the interactions within small groups, and achievement. In particular, this author found that giving and receiving highly elaborated explanations had a positive influence on achievement.

As has been mentioned above, one of the environments that enable students to work in small groups is established within PBL. In PBL active learning is stimulated by discussing problems in so-called tutorial groups under guidance of a tutor (Barrows \& Tamblyn, 1980).

The tutorial group process and the individual learning process play an important role in students learning in a PBL setting. During the tutorial group process, students discuss problems that are to a large extent new to them. In order to understand what this problem is about, they have to activate their prior knowledge. Because students discuss the problem in a group, they are confronted with different explanations. Discussing these differences in opinion, students almost automatically elaborate on the problem. As a result of this small group discussion student become clear what they alrcady know and what they do not know yet. Those topics that need further study become the tutorial group's learning issues. Blumberg and Michael (1992) describc learning issues as factual or conceptual topics that each group decides must be better understood in order to analyze the problem under discussion. These learning issues guide students' individual study activities. In other words. the processes that take place in the tutorial group are assumed to structure the students' 
learning. Although different studies have demonstrated that student-generated learning issues play indeed an important role in the development of self-directed learning skills (Blumberg \& Michael, 1992; Walton \& Matthews, 1989), it is still unclear how these learning issues influence students' individual study. For example, it is not known whether well-defined learning issues are used more frequently by students when searching literature as compared to poorly defined learning issues. In addition, there is a lack of information on what actually happens during individual study. For example, do students make summaries and notes, do they try to formulate the things that they have read in their own words and what is the influence of these activities on the quality of the discussion in the tutorial group afterwards? Do these activities contribute towards a better structure and deeper level of the discussion and ultimately lead to better achievement? Although the studies described above investigate several of the processes in learning in small groups and in PBL, most of these studies only take into account a limited number of variables.

In order to find out what actually takes place in the PBL groups it is interesting to investigate the relations among several variables that seem important for learning in PBL. For instance, Gijselaers and Schmidt (1990) describe a complex set of relations among relevant variables of the process of learning in a problem-based curriculum. They formulated a causal model in which the process of learning in a problem-based curriculum is described. It consists of input (prior knowledge, problems and tutor behaviour), process (study time and group functioning), and outcome variables (achievement and interest in subject matter). Their study showed that well constructed problems strongly determine the process in the tutorial group, and that the tutors' functioning has a positive influence on the functioning of the tutorial group. Furthermore, group functioning has a strong influence on time spent on individual study (see for a detailed discussion, Gijselaers \& Schmidt, 1990). Although the study of Gijselaers and Schmidt gives insight in how elements in the process of learning in a problem-based curriculum are interrelated, to obtain a more detailed understanding of what actually happens to learners in a PBL-context (e.g., during the process of individual study and the reporting in the group) certain parts of the model should be refined.

The present study, therefore, attempts to clarify the relation between generated learning issues, process of individual learning, discussion in the tutorial group and achievement. This process can be described in terms of a causal model shown in Figure 7.1. 
Figure 7.1. Theoretical model representing a part of the learning process in problem-based learning

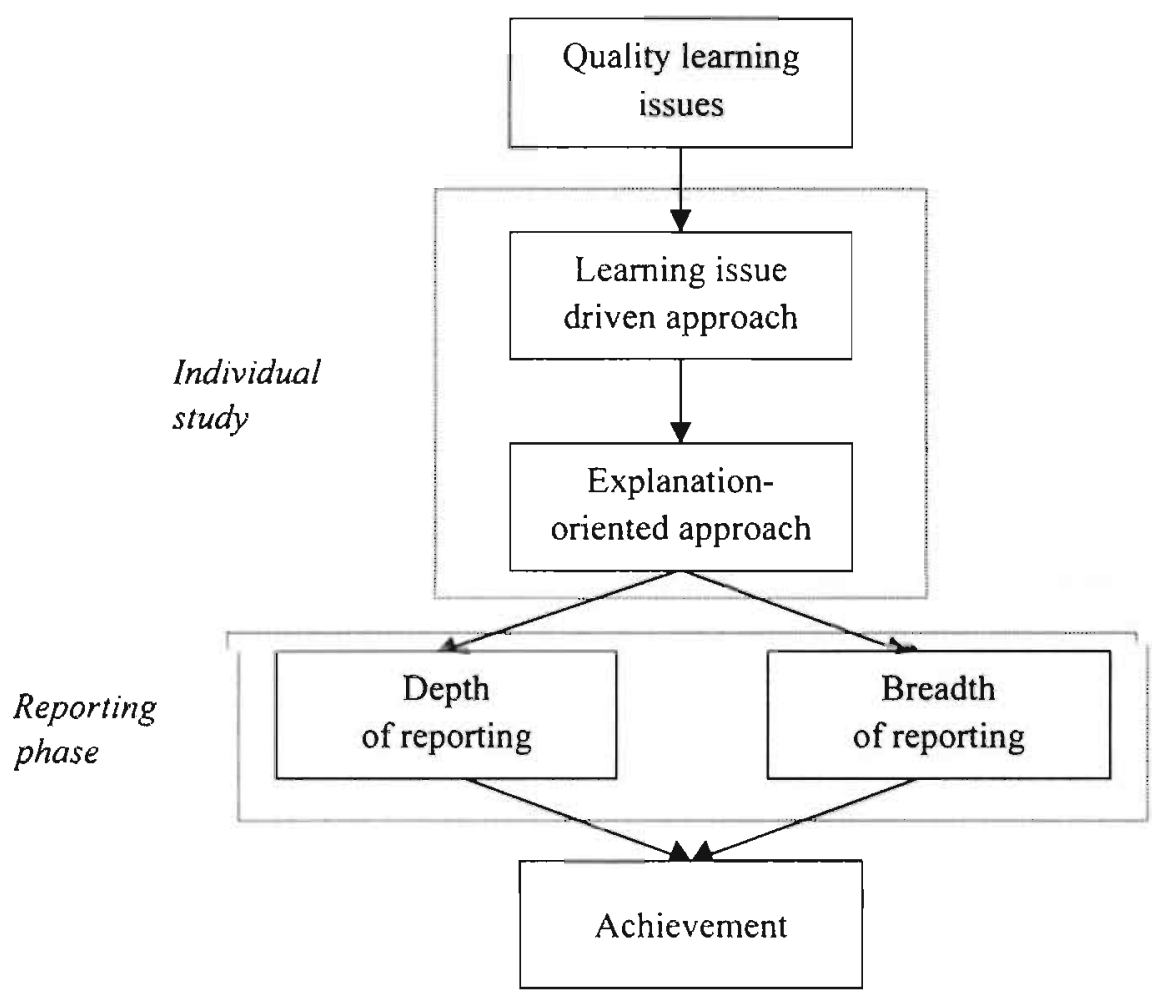

Based on this model, the present study investigates the following research questions. First. does the quality of the generated learning issues influence the extent to which students search literature based on the learning issues formulated? Second, does the extent to which student search for relevant literature by making use of these learning issues, affect the extent to which they will prepare the literature (by defining what is relevant in the text, making summaries and notes, translating the literature in their own words, and by making selections in the text)? Third, does an explanation- 
oriented approach during individual study positively influence the depth and breadth of the reporting in the group? Finally, does a deep and broad reporting in the group lead to a higher achievement?

\section{Method}

\section{Participants}

Participants were all first-year students $(\mathrm{N}=195)$ at the Medical School of the Maastricht University in the Netherlands during the academic year 1997-1998. Students were involved in a problem-based course called 'Attack and Defense.' This course deals with infection and the workings of the immune system. During the third week students completed a questionnaire in which they were asked to answer questions about their activities related to the problem discussed during that specific week. This procedure was repeated for the fourth week (in which a different problem was discussed). During the first measurement 175 students $(90 \%)$ and during the second measurement 171 students $(88 \%)$ responded, spread over 23 tutorial groups. On average in each tutorial group on average nine students participated and at least six students per tutorial group filled in the questionnaire.

\section{Materials}

A questionnaire was developed that contained 22 items reflecting the quality of the learning issues (one factor), process of individual study (two factors), and reporting phase (two factors). The number of items and an example of an item of each factor are shown in Table 7.1. A complete overview of the items is shown in Table 6.1 (Chapter 6).

The first factor, referred to as 'learning issue driven approach,' indicates the use of learning issues when searching learning resources. The second factor was called 'explanation-oriented approach,' indicating whether students studied the literature in order to explain the content to another student by means of making summaries and notes during studying. Two factors referred to the reporting phase: 'depth of discussion,' indicating the extent to which the newly learned information was integrated, and 'breadth of discussion,' illustrating the extent to which a variety of topics related to the problem were discussed. Students were asked to give their opinion on each item using a 5-point Likert scale ranging from (1) totally disagree to (5) totally agree. 
Table 7.1. Examples of items of each of the phases of the model (not including the quality of the learning issues and achievement).

Individual study phase

Learning issue driven searching (5 items)

When I start studying, I use the learning issues as a starting point to determine what literature I will search

Explanation-oriented approach (6 items)

I prepare myself such that I can explain concepts in literature in my own words

Reporting phase

Breadth of discussion (4 items)

When someone found something that was not directly related to the learning issues, it was explained to one another.

Depth of discussion (4 items)

During the discussion the new facts in the tutorial group were integrated and elaborated

To measure the quality of the generated learning issues, students had to fill in the generated learning issues. Furthermore, they scored on a scale from 1 to 10,1 insufficient, 10 being excellent, each learning issue on three characteristics (useful keyword, conciseness and clearness), which appeared in an earlier study to be important characteristics (Van den Hurk, Dolmans, Wolfhagen, \& van der Vleuten, 1998).

Five educational researchers with expertise in the field of problem-based learning and twelve first-year students were asked to judge a draft version of the questionnaire. They were asked whether each item reflected one of the factors.

Achievement was measured by using the mean score of the group on the block-test. In general, the block-test, administered after each block, reflects the content of the foregoing course of six weeks. The major goal is to assess students' knowledge about the course contents and to provide the students with information on their achievement in relation to the course objectives. Fach test is composed of 160 to 190 questions in the true/false format. Students are required to complete the block-test immediately after the end of each six-week course. 
Analyses

The data were aggregated at the tutorial group level by computing mean average scores across students for each tutorial group, and for each factor. This procedure was repeated for the second data set. To assess the quality of the learning issues in each tutorial group, the mean scores of the three characteristics for all learning issues per tutorial group were computed.

To test the reliability of the factors, Cronbach's alpha was calculated. The results showed that the alpha coefficient for the factors varied between 0.64 and 0.74 , except for one factor: the coefficient for the breadth of discussion was 0.53 . The correlation between the factors in the reporting phase $(\mathrm{r}=0.66 ; p<0.01)$ was significant which suggests that these two factors provide limited unique information. The data were analysed using a structural modelling approach. The computer program AMOS 3.6 was used to test the hypothetical interrelationships between the factors in the model (Arbuckle, 1997).

\section{Results}

In Table 7.2 the mean score on each factor is shown. The quality of the learning issues has a mean of 7.1 on a scale from 1 to 10 . There are no large differences in mean scores between the other factors, the lowest score is on the factor 'breadth of discussion' $(M=3.0)$ and the highest score is on the factor 'depth of the discussion' $(M=3.4)$.

Table 7.2. Measurement scale (Scale), Number of items (Items), mean scores on factors (Mean), standard deviation (SD), number of groups (N).

\begin{tabular}{llcccc}
\hline & Scale & Items & Mean & SD & N \\
\hline Quality of generated learning issues & $1-10$ & 3 & 7.1 & 0.5 & 23 \\
Learning issue driven approach & $1-5$ & 5 & 3.1 & 0.3 & 23 \\
Explanation-oriented approach & $1-5$ & 6 & 3.2 & 0.3 & 23 \\
Breadth of discussion & $1-5$ & 4 & 3.0 & 0.4 & 23 \\
Depth of discussion & $1-5$ & 4 & 3.4 & 0.5 & 23 \\
\hline
\end{tabular}




\section{References}

Arbuckle, J.L. (1997). Amos users' guide; version 3.6. Chicago: Smallwaters Corporation.

Barrows, H.S., \& Tamblyn R.M. (1980). Problem-based learning: An approach to medical education. New York: Springer Publishing Company.

Bentler, P.M. (1990). Comparative fit indexes in structural models. Psychological Bulletin, 107, 238-246.

Blumberg, P., \& Michael, J.A. (1992). Development of self-directed learning behaviours in a partially teacher-directed problem-based learning curriculum. Teaching and Learning in Medicine, 4, 3-8.

Brinton, D.A., Jarvis, J.Q., \& Harris, D.L. (1984). A small-group instruction experiment in medical education. Journal of Medical Education, 59, 13-18.

Coles, C.R. (1985). Differences between conventional and problem-based curricula in the students' approach to studying. Medical Education, 19, 308-109.

Gabbert, B., Johnson, D.W., \& Johnson, R.T. (1986). Cooperative learning, groupto-individual transfer, process gain, and the acquisition of cognitive reasoning strategies. The Journal of Psychology, 120(3), 265-278.

Gijselaers, W.H., \& Schmidt, H.G. (1990). The development and evaluation of a causal model of problem-based learning. In Z. Norman, H.G. Schmidt, \& E. Ezzat (Eds.), Innovation in medical education. An evaluation of its present status (pp. 95-113). New York: Springer Publishing Company.

Saris, W.E., \& Stronkhorst, L.H. (1984). Causal modelling in non-experimental research. Amsterdam: Sociometric Research Foundation.

Schmidt. H.G. (1993). Foundations of problem-based learning: some explanatory notes. Medical Education, 27, 422-432. 
Van den Hurk, M.M., Dolmans, D.H.J.M., Wolfhagen, H.A.P., \& Van den Vleuten, C.P.M. (1998). Essential characteristics of student-generated learning issues in a problembased curriculum. Medical Teacher, 20(4), 307-309.

Walton, H.J., \& Matthews, M.B. (1989). Essentials of problem-based learning. Medical Education, 3, 542-558.

Webb, N. (1985). Students interaction and leaming in small groups: A research summary. In R.E. Slavin, S. Sharan, R. Kagan, C. Hertz-Lazarowitz, N. Webb, and $\mathrm{R}$. Schmuck (Eds.), Learning into cooperate, cooperating to learn (pp. 147-172). New York: Plenum.

Webb, N.M., Troper, J.D., \& Fall, R. (1995). Constructive activity and learning in collaborative groups. Journal of Educational Psychology, 87(3), 406-423. 


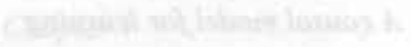

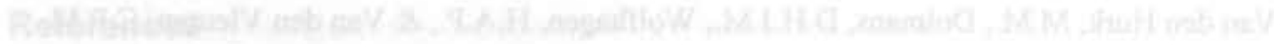

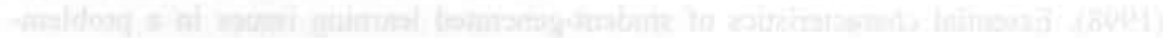

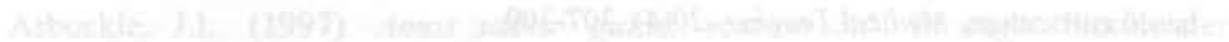

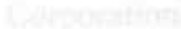

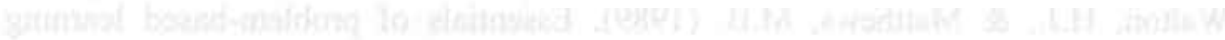

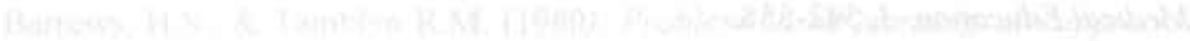

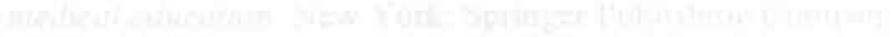

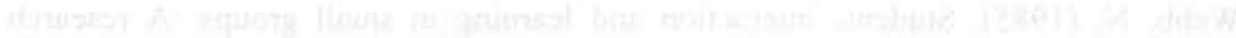

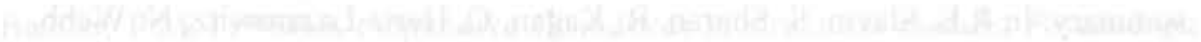

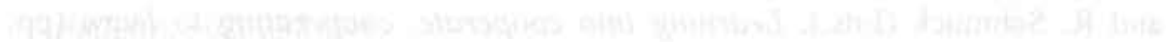

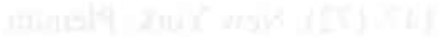




\section{8}

\section{Conclusions and Implications}

The central theme of this thesis concerned the way that ideas and findings on learning and instruction influence student learning in problem-based leaming (PBI.). Especially, it was questioned how steps preceeding and following individual study in PBL influence individual study and student learning. To explore this central theme. three main research topics were investigated. First, what is the impact of time spent on individual study on achievement, described in Chapter 2? Second. what is the relation between student-generated learning issues on individual study, addressed in Chapters 3,4 and 5? Finally, what is the influence of individual study on tutorial group processes described in Chapters 6 and 7 ? The conclusions of each Chapter are summarized and some general conclusions concerning the three research questions are made. Subsequently, educational implications of the results are outlined. Finally, suggestions for further research raised by the studies are given.

\section{Findings and general conclusions}

In the next paragraph an overview of the findings are outlined from the studies to answer the three main research questions. General conclusions that can be drawn on these findings are formulated.

\section{The impact of time spent on individual study on achievement}

In Chapter 2 the relation was examined between time spent on individual study and academic achievement in a problem-based curriculum. The hypothesis tested was whether more time spent on individual study resulted in better achievement on tests measuring knowledge acquired during this individual study. The results suggested that time spent on individual study poorly correlates with test. scores. The study only 
explored the time students actually spent in learning. It was not investigated whether time allowed or allocated for individual learning sufficed, or how much time students actually needed for learning. It was argued that students in a problem-based curriculum have sufficient time for individual learning, because instruction time is limited and considerable time is scheduled for individual study. Compared to more traditional curricula the PBL curriculum leaves a substantial amount of time for individual study. However, this does not mean that students always use the time available for individual study. A more plausible explanation for the poor relation between time spent on learning and achievement is that students differ in the time they need to learn.

In general, this study reaffirms the complexity of the relationship between time spent on individual study and achievement and it demonstrates the importance to search for qualitative factors about the way students learn during individual study. Although time variables play a central role in learning, it is also important to focus on how students learn during their individual study and what influences their learning.

\section{The influence of student-generated learning issues on individual study}

In Chapters 3 to 5 it was investigated how the process in the tutorial group influences the generation of useful learning issues and to what extent learning issues direct students' individual study. In Chapter 3, three questions were investigated: First, what is the impact of the tutorial group process on generating useful learning issues? Second, when and how are learning issues used during individual study? Third, what determines the selection of literature during individual study? It was also investigated whether this interacted with years of training.

In order to answer the first question, it was hypothesized that several elements of the tutorial group, including discussion and the quality of problems. might influence the generation of learning issues. The results on the first research question indeed showed that generating useful learning issues depends on the quality of the discussion in the tutorial group, the quality of the problems discussed and on tutor behavior in all years of training.

Results on the second research question showed that first-year students use leaming issues most extensively before and during individual study. This usage decreases during the years of training. The results showed furthermore that students use learning issues especially as a guide to select the literature. The results of Chapter 3 
support the assumption that learning issues are a major driving force for initiating students' learning activities.

Concerning the third research question in Chapter 3; which factors determine the selection of literature, it was found that literature references in the block book or given by the tutor have a strong impact on the selection of literature in all years. The course objectives also influenced the selection of literature in all years of training. It is not surprising that students in selecting learning resources focus on the provided literature references, because they give direction on the topics to be studied.

Since it was not clear what students assume to be useful learning issues, this issue was further investigated in Chapter 4 . The characteristics were investigated which make learning issues useful for individual study and variability in the importance of these characteristics across the years of training. Students reported three important characteristics brought together in one definition: a useful learning issue contains a keyword that demarcates the content of a certain topic to be studied and is formulated concisely and unambiguously for all members of the tutorial group. There were small differences in the importance of the characteristics between years of training. Beginning students think it is more important that learning issues are formulated concisely, whereas senior students stress the importance of a useful key word.

The aim of the study reported in Chapter 5 also dealt with the relation between learning issues and individual study. The aim of this study was twofold. The first question concemed the way students make use of the learning issues they generate (as strict guidelines or as global guidelines) and whether this changed across years of training. The second question dealt with the relation between the way students used the learning issues, the time spent on individual study and achievement. Results showed that students in the first year study strictly according to the content of the learning issues whereas students in later years also study more according to their own learning needs and interests. In addition, students who tend to study beyond the. generated learning issues, spend more time on individual study and achieved better on tests.

In gencral, Chapters 3 to 5 demonstrate that student-generated learning issues play an important role in the development of students' independent learning. First, by discussing problems in the tutorial group, students learn to see gaps in their own knowledge and learn to decide what issues need to be studied in further detail. The second crucial role of leaming issues is that they play an important role in the 
process of regulating independent learning. In problem-based learning, the generated learning issues give students the opportunity to learn what they think is relevant to study in order to meet their own educational needs. Students with more experience in problem-based learning use learning issues more as global guidelines, tune their learning activities more and more to their own educational needs, which seems to demonstrate that they become better self-directed learners.

\section{The impact of individual study on tutorial group discussion}

Two Chapters dealt with the relation between individual study and the tutorial group discussion afterwards, the so-called reporting phase. In Chapter 6 the relationship between individual study and group discussion after individual study was investigated. It was expected that the way students prepare themselves during individual study (i.e., search and prepare the literature) influences the quality of the reporting phase. Searching the literature dealt with the extent to which students search for different resources. Preparing the literature was defined as the extent to which students make summaries of the literature and study the literature in order to explain it to other students. The results showed that the search - and preparation phase contributed equally to the amount of explained variance related to the breadth of riporting. Preparing extensively for the next tutorial meeting furthermore strongly influcnces the depth of the reporting phase.

Thu aim of Chapter 7 was to identify structural relations between the quality of student-yenterated learning issues. a learning issue driven approach, an explanationoricnted approach, reporting in the tutorial group and achievement. A structural model was developed and tested. The results indicated that the model fitted the data well. In this model, the quality of the learning issues positively influenced a learning issue driven approach, which in return positively influenced an explanation-oriented approach. The explanation-oriented approach positively influenced the depth and breadth of the discussion. Finally, the depth of the discussion positively influenced achievement.

In general, Chapters 6 and 7 demonstrate that the extent to which students prepare themselves strongly predicts the quality of the tutorial group discussion (i.e., by making summaries and studying the materials in order to explain it to other students) and ultimately students' achievement. Preparation during individual study and group discussion afterwards seem important for a deeper level of understanding. 
The studies described in this thesis were aimed at gaining insight in how students learn in a problem-based curriculum. It was concluded that time spent on individual study was not directly related to achievement, but students who study beyond the learning issues, spent more time on individual study and also achieve better. Thus, learning issues play a crucial role in the development of students' self-directed learning skills. In addition, students' preparation during their individual study for the next tutorial meeting is important. The reporting will reach a deeper level if students prepare themselves better during individual study for the reporting in the tutorial group, which will subsequently lead to higher achievement.

\section{Educational implications}

The results of the first research question that is what is the relation between time spent on individual study and achievement, demonstrate that time spent on individual study correlates poorly with test scores. One of the explanations for this finding was that students differ in the time they need to learn. In a problem-based curriculum ample time is scheduled for individual study. However, it is important that students develop skills to manage this time effectively. In their first year of training students should learn how to schedule time for individual study each day, how to schedule this time during the week, etcetera. If students know how much time they actually need to understand the materials at a deep level, they will be better able to optimize their individual study activities.

Concerning the results of the second research question, i.e. the relation between the student-generated learning issues and individual study, several implications for improving PBL can be given. First, it is important for the generation of useful learning issues that the discussion is well structured. The discussion in the tutorial group is guided by a discussion leader, always a member of the group, who has an important but a difficult task to structure the discussion. Although students are trained to perform this role, leading the discussion can still be difficult for them. Students must become aware of their strengths and of aspects that need further practice in performing the role of discussion leader. The tutor can be helpful in this process. Evaluating the process in the tutorial group at a regular basis will be helpful to improve and refine the performances of the discussion leader. In daily practice in PBL, it can happen that after a long and intensive analysis of the problem, students and tutors think that they have fulfilled the most important task: they analyzed the 
problem and know what needs to be studied. Sometimes only limited time is spent on formulating learning issues, leading to less accuracy in formulating the learning issues. However, since learning issues should demarcate the literature to be studied, the formulation should be done with full attention of all members of the group. Tutors and students should also be trained to generate and evaluate the learning issues on their usefulness for individual study. The results on the third research question furthermore showed that first-year students confine themselves more strictly to the content of learning issues; use a more learning issue restrictive approach. This implies that they are answering the learning issues step-by-step, using them as a tool to demarcate the literature. Senior students use a more learning issue broadening approach, and study not only according to the topics directly related to the learning issues generated. First-year students should indeed be recommended to confine themselves to the learning issues because they may loose track of the central issues to be studied. However, during the years of training, students are expected to increasingly regulate their own learning by tuning the leaming issues more to their own educational needs and should therefore use learning issues more as global guidelines. This implies that instruction must reduce students'dependence on external regulation. Beginning students can be provided with clues and directions that guide them in their decision in what to study. During the years of training, as students become more skilled in the self-regulatory process, this guidance should decrease.

Research question 3, i.e. what is the impact of individual study on tutorial group discussion, led to the important conclusion that especially the extent to which students prepare the literature in an explanation-oriented way determines the depth of the reporting phase. This implies that not only students must learn to give explanations during the discussion, they must also be taught how to prepare for the reporting in the group after individual study by asking themselves whether they can explain the materials studied to other students in their own words.

\section{Further research}

The studies presented in this thesis reveal several questions that need further research.

It was shown that what happens in the tutorial group strongly determines student learming. Especially, the reporting phase is of significant importance for students" 
achievement. Future research should therefore focus more on the process of learning during the reporting phase. Several questions about the reporting phase are interesting to investigate in further detail. For example, what factors infiuence the quality of interactions during the reporting? To what extent do students study different literature resources and how does this influence the reporting phase and achievement? Do students achieve better when they explain concepts to others compared to when they only receive explanations? It was concluded that the extent to which students prepare the literature by making summaries and prepare themselves in order to explain the literature, has a strong impact on the quality of the discussion. The studies however, lack in providing detailed information about the quality of the summaries that students make how exactly they should prepare themselves for the next meeting. In further research it would be interesting to collect summaries and qualify them on their usefulness for the reporting in the tutorial group. Furthermore, it is worthwhile to investigate how students prepare themselves to explain concepts to other students.

In order to find out what actually takes place in the PBL groups in relation to students' learning this thesis has investigated the relations among several variables. Describing and testing them in a causal model revealed better insight in how elements in the process of learning in a problem-based curriculum are interrelated. However, the model of learning in PBL could still be developed in further detail.

Finally, the results of this thesis seem to indicate that students become better selfdirected learners. However, it is not yet clear whether these skills are maintained in professional career. In other words. do students acquire the ability to continue their education after they graduate? It would be interesting to develop a longitudinal study to follow students after graduation during their professional career. Do PBL-students make more use of the library after graduation. Are they still able to identify their own educational needs and how do they fulfil them. 



\section{Summary}

The central theme of this thesis was how ideas and findings on learning and instruction influence student learning in problem-based learning. In particular, the way the steps preceding and following individual study in problem-based learning was investigated. To gain more insight in this, three main research topics were investigated. First, what is the impact of time spent on individual study on achievement? Second, what is the relation between student-generated learning issues and on individual study? Finally, what is the influence of individual study on tutorial group processes?

The first main topic of this thesis was about the impact of time spent on individual study on achievement.

Chapter 2 examined whether a relation existed between time spent. on individual study and academic achievement in a problem-based curriculum. Time spent on individual study was measured by a self-report procedure. After each block of six. weeks students were asked to estimate the average amount of time spent on individual study per weck during that block. Achievement was measured with two tests methods. The first was the block-test. In general, the block-test, taken after each block, reflects the content of the foregoing block of six. weeks.

The other method was the progress-test. In general, all students of every level are required periodically to take the progress-test, a large test at graduate level, sampled from the total medical body of knowledge, four times a year.

The results showed that time spent on individual study poorly correlates with scores on the block-test and also with those on the progress-test. An explanation for these findings was that students will master instructional objectives to the extent that they have had the opportunity to learn and are willing to invest the time needed to learn. To be more specific, three time variables may contribute to variability in achievement across individual students. These are time allowed or allocated for learning, time spent or engaged in learning and time actually needed for learning. Achievement is then maximized if time spent increases to the point where it equals the amount of time actually needed to learn. In the study reported in chapter 2 only the time students' actually spent in learning was explored. In PBL, instruction time 
is limited and considerable time is scheduled for individual study, hence time allowed for learning should he sufficient. The most plausible explanation should be found in the time students actually need for learning. Students differ in the time they need to leam related to a level of achievement that can be explained by intelligence, learning styles or the influence of the curriculum. This study reaffirmed the conplexity of the relationship between time spent on individual study and achievement and it demonstrates the importance to search for qualitative factors about the way students learn.

The second main topic of this thesis was about the relation between studentgenerated learning issues and individual study.

In Chapter 3, three research questions were investigated: First what is the impact of the tutorial group process (i.e., discussion in the tutorial group, tutor, and problems) on generating useful learning issues? Second when and how are learning issues used during individual study? Third, what determines the choice of literature during individual study? On the basis of interviews, a questionnaire was developed that contained 36 items. These items were aimed at measuring elements in the tutorial group that are important in generating useful leaming issues (i.e., tutor, task and group discussion), questions about the use of learning issues (i.e., when and how are learning issues used) and about factors that might influence choice of literature (i.e., course objectives, assessment, lectures, practicals and literature references). The results on the first research question, showed that generating useful learning issues in all years mostly depends on the quality of the discussion in the tutorial group, the quality of the tasks and on the functioning of the tutor. Results on the second research question showed that first-year students use learning issues most extensively before and during individual study. This decreased during the years. The results on the way that students use the learning issues, showed that learning issues especially have a function as a guide to select the literature students plan to study and not as a guide to prepare for the tests.

Concerning the third rescarch question in Chapter 3, results showed that literature references in the block book or given by the tutor have most impact on the selection of litcrature. The course objectives also influenced the selection of literature. It was concluded that students in selecting leaming resources focus on literature references beciuse they provide direction on the topics to be studied. However, by conducting literature searches students acquire the ability to select learning materials independently. 
In Chapter 4 it was investigated what the essential characteristics of learning issues are. Subsequently, it was investigated whether the importance of these characteristics differs between years of training. Students answered two (free response) questions about characteristics of learning issues. Three important characteristics were mentioned, brought together in one definition: a useful learning issue contains a keyword that demarcates the content of a certain topic to be studied and is formulated concisely and unambiguously for all members of the tutorial group. There were small differences in the importance of the characteristics between years of training. Students in the first year think it is important that learning issues are formulated concisely, whereas senior students stress the importance of a useful keyword. Later year students therefore seem to use learning issues more as global guidelines that provide a rough direction for their individual study activities.

In Chapter 5 two research questions were investigated. The first question concerned the way students make use of the learning issues they generate (i.e., as strict guidelines or as global guidelines) and whether this changes across years of training. The second question was about the relation between the way students used the learning issues and the time spent on individual study and achievement on two tests of knowledge. A questionnaire was developed that contained seven items that measured to what extent students study strictly according to the student-generated learning issues and six items that measured to what extent students study beyond the student-generated learning issucs. The questionnaire also contained one question in which students had to estimate the mean time spent on individual study. Two test methods. a block-test assessing six-week block content and a progress test assessing long-term functional knowledge, were used to measure students' achievement.

The results showed that students in the first year study more strictly according to the content of the learning issues whereas students in later years study more according to their own learning needs and interests. In addition, the results showed that students who tend to study beyond the generated learning issues, spent more time on individual study and achieved better on both tests. These results indicate that students in a problem-based curriculum seem to become better self-directed learners during the years of training since learning issues in later years are more and more directed towards their own learning needs and interests.

The third main topic of this thesis was about the influence of individual study on tutorial group processes. 
In Chupter o the relationship between individual study and group discussion was investigated. It was expected that the way students prepare themselves during individual study influences the quality of the reporting in the tutorial group. To investigate this expectation. a questionnaire was developed containing 23 items reflecting five factors. Three factors reflecting the individual study: (1) "Learning issue driven searching," indicating the use of learning issues when searching learning resources, (2) "Extensiveness of searching," suggesting the extent to which students searched and compared different learning resources, and (3) "Explanationoriented," indicating whether students studied the literature in order to explain the content to other students by making summaries and notes during studying. Two factors reflecting the reporting in the tutorial group: (4) "Breadth of reporting," illustrating the extent to which a variety of literature resources were used during the reporting phase and (5) "Depth of reporting," indicating the extent to which the newly leamed information was integrated.

The results on the question what factors in the individual study mostly influence the reporting in the tutorial group, showed that all factors explained $29 \%$ of the variance of the breadth and $38 \%$ of the depth of the reporting phase. The factors contributed almost equally to the amount of explained variance of the breadth of the reporting, however, the depth of the reporting was mostly explained by the extent to which students studied the literature for explaining it to others. It was concluded that preparing in order to explain literature for the next tutorial mecting is very important for especially the depth of the reporting phase.

Chapter 7 investigated the relationship between problem-based process elements, which are important for the tutorial group process and for the individual study in a problem-based curriculum. A model was developed and tested. In this model the variables quality of student-generated learning issues, learning issue driven approach and explanation-oriented approach were assumed to influence the depth and breadth of the reporting in the tutorial group. Subsequently, the depth and breadth of the reporting were assumed to influence achievement. The results on the questionnaire described in Chapter 6 were used. The data were analyzed using a structural modelling approach. The results indicated that the developed model fitted the data well. The path coefficients were moderately high, particularly between the explanation-oriented approach and the depth of the reporting in the tutorial group. High path coefficients were also found between the depth of the reporting and achievement. In sum, the model gives insight in how important variables are related and it is recommended that data should be collected to test the model repeatedly. 
In chapter 8 a general conclusion was drawn. It was concluded that time spent on individual study was not directly related to achievement, but students who study beyond the leaming issues, spent more time on individual study and also achieve better. Thus, learning issues play a crucial role in the development of students' selfdirected leaming skills. In addition, students' preparation during their individual study for the next tutorial meeting is important. The reporting will reach a deeper level if students prepare themselves better during individual study for the reporting in the tutorial group, which will subsequently lead to higher achievement. 



\section{Samenvatting}

Het centrale thema van dit proefschrift is het leren van studenten binnen het probleemgestuurd onderwijs. De studies zijn uitgevoerd aan de Medische Faculteit van de Universiteit Maastricht die gekenmerkt wordt door een probleemgestuurd curriculum. In groepen van 8 tot 10 studenten worden, onder begeleiding van een tutor, taken bediscussieerd. Tijdens de discussie activeren studenten de aanwezige voorkennis en genereren ze ideeën over de onderliggende concepten of mechanismen die in de taak beschreven zijn. Deze discussie resulteert uiteindelijk in een aantal onbeantwoorde vragen die vervolgens geformuleerd worden als leerdoelen. De leerdoelen dienen als leidraad voor hun zelfstudie-activiteiten, zoals het zoeken naar relevante literatuur. In de volgende bijeenkomst van de onderwijsgroep rapporteren studenten hun bevindingen aan elkaar en proberen ze de nieuwe informatie te synthetiseren.

In de studies zoals beschreven in dit proefschrift zal met name worden ingegaan op de zelfstudie van studenten in relatie tot verschillende factoren uit het curriculum. Dat wil zeggen, welke factoren beïnvloeden de zelfstudie en hoe beïnvloedt zelfstudie het onderwijsproces? De volgende drie thema's komen hierbij aan de orde. Ten eerste, wat is de invloed van tijd besteed aan zelfstudie op toetsprestatie? Ten tweede, wat is de relatie tussen leerdoelen die studenten genereren en zelfstudie? Tenslotte, wat is de invloed van zelfstudie op het onderwijsgroepsproces?

Het eerste thema van dit proefschrift betreft de relatie tussen zelfstudietijd en toetsprestatie centraal en zal worden uitgewerkt in Hoofdstuk 2.

In Hoofdstuk 2 wordt onderzocht of de tijd besteed aan zelfstudie van invloed is op de toetsprestaties. Tijd besteed aan zelfstudie is gemeten met een "retrospectieve" procedure. Dat wil zeggen, studenten dienen na ieder blok van zes weken een schatting te maken van de tijd die zij gedurende het betreffende blok gemiddeld per week besteed hebben aan zelfstudie. De toetsscore wordt gemeten door middel van twee meetinstrumenten: de bloktoets en de voortgangstoets. De bloktoets wordt na elk blok afgenomen en reflecteert de inhoud van het voorafgaande blok. De 
voortgangstoets is een kennistoets die vragen bevat over het gehele kennisdomein van de studie en wordt vier keer per jaar afgelegd door alle studenten. Uit de resultaten blijkt dat de tijd die studenten besteden aan zelfstudie nauwelijks correleert met scores op de bloktoets en op de voortgangstoets. In de studie van Hoofdstuk 2 werd gekeken naar de tijd die studenten besteed hebben aan zelfstudie. Een verklaring voor de lage correlaties kan liggen in het feit dat studenten niet voldoende tijd beschikbaar hebben voor hun zelfstudie. Echter, de hoeveelheid tijd die ingeroosterd is voor zelfstudie in probleemgestuurd onderwijs is aanzienlijk, waardoor het onwaarschijnlijk is dat studenten als gevolg van teveel contacturen te weinig zelfstudietijd hebben. Een altematieve verklaring voor de lage correlaties tussen zelfstudietijd en toetsprestatie kan beter gezocht worden in de tijd die studenten nodig hebben om te leren. Om tot een bepaalde toetsprestatie te komen, kunnen studenten variëren in de tijd die zij hiervoor nodig hebben door verschil in leerstijl, intelligentie, of door de invloed van ficturen uit het curriculum zoals bijvoorbeeld de onderwijsvorm. Deze studie bevestigt de complexe relatie tussen zelfstudietijd en toetsprestatie en daarmee het belang van het zoeken naar factoren die van invloed zijn op de wijze waarop studenten leren.

Het tweede thema betreft de relatie tussen de leerdoelen die studenten genereren in de onderwijsgroep en zelfstudie. Deze studies staan beschreven in Hoofdstuk 3, 4 en 5.

In Hoofdstuk 3 is het tweede thema geoperationaliseerd in drie subvragen: ten eerste, wat is de invloed van het onderwijsgroepsproces op het genereren van bruikbare leerdoelen? Ten tweede, wanneer en hoe worden leerdoelen gebruikt gedurende de zelfstudie? Ten derde, waardoor wordt de keuze van de literatuur beïnvloed? Om inzicht in deze vragen te krijgen zijn allereerst interviews afgenomen bij 12 studenten. Op basis hiervan is een vragenlijst met 36 items samengesteld. Deze items veronderstellen aliereerst elementen uit de onderwijsgroep te meten die van belang geacht worden in het genereren van bruikbare leerdoelen (discussie in onderwijsgroep, tutor en taken). Hiernaast meten de items het gebruik van leerdoelen en tenslotte factoren die de literatuurkeuze bepalen (blokdoelstellingen, toets, colleges, practica en literatuur referenties).

De resultaten betreffende de eerste onderzoeksvraag tonen aan dat het genereren van bruikbare leerdoelen in alle leerjaren vooral bepaald wordt door de kwaliteit van de discussie in de onderwijsgroep. Tevens is de kwaliteit van de takin en het functioneren van de tutor van belang. De resultaten op de tweede onderzoeksvraag 
laten zien dat eerstejaarsstudenten de leerdoelen voor en tijdens de zelfstudie uitgebreid gebruiken. Dit gebruik van leerdoelen neemt echter gedurende de studie geleidelijk af. De resultaten tonen verder aan dat studenten de leerdoelen vooral belangrijk vinden als leidraad om de literatuur te bestuderen.

Wat betreft de derde onderzoeksvraag in Hoofdstuk 3 laten de resultaten zien dat de literatuur referenties in het blokboek de meeste invloed hebben op de literatuurkeuze. De blokdoelstellingen zijn iets minder van invloed op de literatuurkeuze.

Uit de studie in Hoofdstuk 3 kan geconcludeerd worden dat leerdoelen een belangrijke rol spelen in de zelfstudie en dat de onderwijsgroep van belang is voor het genereren van bruikbare leerdoelen en dat deze vervolgens een sturende werking in de zelfstudie hebben. Echter, de studie geeft geen inzicht in wat precies bruikbare leerdoelen zijn en dit zal derhalve in de volgende studie verder onderzocht worden. In Hoofdstuk 4 is onderzocht wat essentiële kenmerken van bruikbare leerdoelen zijn en of er verschillen te vinden zijn tussen de leerjaren. Studenten hebben twee open vragen naar kenmerken van bruikbare leerdoelen beantwoord. Hieruit komen drie essentiële kenmerken naar voren. die samengebracht zijn in een definitie: een bruikbaar leerdoel bevat een kernwoord dat een gedeelte van een onderwerp dat bestudeerd dient te worden afbakent, het is bondig geformuleerd en eenduidig te interpreteren voor alle leden van de onderwijsgroep. Er zijn kleine verschillen tussen de vier leerjaren over de meest belangrijke kenmerken. Studenten in het eerste jaar vinden het vooral belangrijk dat een leerdoel bondig is geformuleerd terwijl studenten in het derde en vierde jaar het vooral belangrijk vinden dat een leerdoel een kernwoord bevat. Dit lijkt erop te wijzen dat gevorderde studenten leerdoelen meer als een globale leidraad gebruiken, die richting dient te geven aan hun zelfstudieactiviteiten.

In hoeverre deze veronderstelling juist is, wordt in het volgende hoofdstuk onderzocht.

In Hoofdstuk 5 staan twee onderzoehsvragen centraal. De eerste vraag betreft de wijze waarop studenten de leerdoelen gebruiken die zij generercn (als strikte leidraad of als globale leidraad) en of dit verandert gedurende de vier leerjaren. De tweede vraag is wat de invloed is van de wijze waarop leerdoelen gebruikt worden op de tijd besteed aan zelfstudie en op toetsprestatie. Een vragenlijst is ontwikkeld waarin zeven items de mate waarin studenten strikt volgens de leerdoelen studeren reflecteren en zes items de mate waarin studenten leerdoeloverstijgend studeren. De vragenlijst bevat tevens een vraag waarin studenten retrospectief hun zelfistudietijd 
rapporteren. Twee toetsmethoden zijn gebruikt, de scores op bloktoets en de scores op de voortgangstoets. De resultaten laten zien dat studenten in het eerste jaar meer leerdoelbeperkt studeren terwijl studenten in latere jaren meer volgens hun eigen leerbehoeften en interesses studeren. Vervolgens tonen de resultaten aan dat studenten die meer leerdoeloverstijgend studeren, meer tijd besteden aan zelfstudie en hogere toetsprestaties behalen. Deze resultaten ondersteunen de gedachte dat studenten in een probleemgestuurd curriculum in het verloop van hun studie meer zelfwerkzaam worden.

In het derde thema van dit proefschrift staat de invloed van de zelfstudie op het onderwijsgroepsproces centraal.

In Hoofdstuk 6 is de relatie tussen zelfstudie en de nabespreking in de onderwijsgroep onderzocht. De veronderstelling is dat de wijze waarop studenten zich voorbereiden tijdens de zelfstudie van invloed is op de kwaliteit van de nabespreking in de onderwijsgroep. Om dit te onderzoeken is een vragenlijst ontwikkeld met 23 items die vijf factoren reflecteren. Drie factoren reflecteren de zelfstudie: (1) "Leerdoelgericht zoeken", de mate waarin leerdoelen gebruikt worden tijdens het selecteren van literatuur, (2) "Uitgebreidheid van zoeken", de mate waarin studenten zoeken naar verschillende leerbronnen, en (3) "Uitleg-georiënteerd studeren", de mate waarin studenten de leerstof bestuderen om het vervolgens uit te leggen aan andere studenten. Twee factoren reflectereren de nabespreking in de onderwijsgroep: (4) "Uitgebreidheid van de nabespreking", de mate waarin verschillende literatuurbronnen aan de orde komen, (5) "Diepgang van de nabespreking", de mate waarin de leerstof geïntegreerd en uitgediept wordt. De resultaten laten zien dat alle factoren uit de zelfstudie samen $29 \%$ van de variantie in de uitgebreidheid van de nabespreking en $38 \%$ van de diepgang in de nabespreking verklaren. De uitgebreidheid van de nabespreking wordt door bijna alle factoren evenveel verklaard, terwijl de diepgang van de nabespreking vooral verklaard wordt door de mate waarin studenten de leerstof zodanig bestuderen dat zij het aan andere studenten kunnen uitleggen.

In Hoofdstuk 7 is de relatie onderzocht tussen elementen uit het onderwijsgroepsproces en de zelfstudie. Vervolgens is er een theoretisch model geconstrueerd. In dit model is de kwaliteit van leerdoelen, leerdoelgericht studeren. en uitleg-georiënteerd studeren van invloed op de uitg̣ebreidheid en de diepgang van de nabespreking in de onderwijsgroep. Vervolgens is de uitgebreidheid en de diepgang van de nabespreking van invloed op de toetsprestatie. De vragenlijst uit 
Hoofdstuk 6 is opnieuw gebruikt. De resultaten laten zien dat het theoretische model past op de gevonden data. De padcoëfficiënten zijn hoog; vooral uitleg-georiënteerd studeren en de diepgang van de nabespreking in de onderwijsgroep. Ook zijn hoge padcoëfficiënten gevonden tussen de diepgang van de nabespreking en de toetsprestatie. Kortom, het model geeft inzicht in hoe belangrijke variabelen in het leerproces met elkaar samenhangen.

Hoofdstuk 8 beschrijft een algemene conclusie. Geconcludeerd wordt dat de zelfstudietijd niet direct van invloed is op toetsprestatie, maar dat studenten die leerdoeloverstijgend studeren wel meer tijd aan zelfstudie besteden en hogere toetsscores behalen. Leerdoelen lijken een cruciale rol te spelen in de ontwikkeling van de zelfwerkzaamheid in het leren van studenten. Ook de voorbereiding tijdens de zelfstudie op de nabespreking in de onderwijsgroep is van groot belang. De nabespreking heeft meer diepgang wanneer studenten zich gericht voorbereiden op het uitleggen van de leerstof aan andere studenten in de onderwijsgroep, wat vervolgens zal leiden tot een hogere toetsscore. 
broowlnis C 


\section{Curriculum Vitae}

Marianne van den Hurk was born on November 1, 1966 in Veghel. She finished HAVO in 1984 at Mgr. Zwijssencollege in Veghel. In 1984 she started to study social pedagogical work at the Hogeschool Nijmegen, which she completed in 1988. Subsequently, she studied Educational Psychology at the University of Nijmegen. Since graduation in 1993, she has been working at the Institute for Higher Professional Education in Nijmegen in a research project on causes of dropout in Higher Education.

In March 1995 she started her Ph.D. research at the Department of Educational Development and Research at the Medical Faculty of the Maastricht University. Since February 1999 she works as an assistant professor at the Departments of Psychology and Health Sciences of the Maastricht University. 
